\title{
UMA HISTÓRIA POLÍTICA DA TRANSIÇÃO BRASILEIRA: DA DITADURA MILITAR À DEMOCRACIA ${ }^{1}$
}

\author{
Adriano Nervo Codato
}

\begin{abstract}
RESUMO
O artigo trata da história política brasileira do golpe político-militar de 1964 ao segundo governo de Fernando Henrique Cardoso. Escrito sob a forma de um resumo explicativo, três temas unificam a narrativa sobre a transição do regime ditatorial-militar para o regime liberal-democrático: o militar, o político e o burocrático. Procura-se estabelecer inferências causais entre o conteúdo, o método, as razões e o sentido da mudança política a partir de 1974 e a qualidade do regime democrático na década de 1990. A explicação destaca a necessidade de se analisar dois espaços políticos diferentes, mas combinados: as transformações no sistema institucional dos aparelhos do Estado e as evoluções da cena política. Conclui-se que as reformas econômicas neoliberais não apenas prescindiram de uma verdadeira reforma política que aumentasse a representação, e de uma reforma do Estado que favorecesse a participação. As reformas neoliberais tiveram como precondição o arranjo autoritário dos processos de governo herdados do período político anterior.
\end{abstract}

PALAVRAS-CHAVE: política brasileira (1964-2002); regime ditatorial-militar; transição política; democracia; neoliberalismo.

\section{INTRODUÇÃO: QUESTÕES DE TERMINO- LOGIA E PERIODIZAÇÃO}

No Brasil, o regime ditatorial-militar durou 25 anos, de 1964 a 1989, teve seis governos - incluindo um governo civil - e sua história pode ser dividida em cinco grandes fases.

Uma primeira fase, de constituição do regime político ditatorial-militar, corresponde, grosso modo, aos governos Castello Branco e Costa e Silva (de março de 1964 a dezembro de 1968); uma segunda fase, de consolidação do regime ditatorial-militar (que coincide com o governo Medici: 1969-1974); uma terceira fase, de transformação do regime ditatorial-militar (o governo Geisel: 1974-1979); uma quarta fase, de desagregação do regime ditatorial-militar (o governo Figueiredo: 1979-1985); e por último, a fase de transição do regime ditatorial-militar para um regime liberal-democrático (o governo Sarney:

1 Uma versão diferente deste artigo, destinada ao público estrangeiro, aparecerá em 2006 no volume organizado por mim (CODATO, 2006), sob o título "Political Transition and Democratic Consolidation in Brazil: a Historical Perspective”.
1985-1989).

Já de início, três aspectos devem ser destacados nesse longo período. Primeiro, o processo de "distensão política", depois chamado "política de abertura” e, por fim, "transição política”, foi iniciado pelos militares, e não por pressão da "sociedade civil”, ainda que ela tenha influído, de maneira decisiva, menos no curso e mais no ritmo dos acontecimentos. Segundo, esse processo teve sua natureza, andamento e objetivos determinados também pelos militares ou, mais exatamente, por uma de suas muitas correntes político-ideológicas. Por fim, ele correspondeu à necessidade dos próprios militares resolverem problemas internos à corporação, e não a uma súbita conversão democrática de parte do oficialato ${ }^{2}$.

2 Bárbara Geddes nota que “diferentes tipos de autoritarismo entram em colapso de modo caracteristicamente diferentes [...]. Um estudo de 163 regimes autoritários em 94 países oferece provas de que existem realmente diferenças entre os padrões de colapso [...]”. Classificando os "regimes autoritários" em três subtipos, personalista, militar e de partido único, Geddes argumenta que "as transições do governo militar começam usualmente com divisões dentro da elite militar governante [...]. Há [...] um 
O controle que as Forças Armadas exerceram sobre o aparelho do Estado e sua presença ostensiva na cena política acabaram por importar uma série de conflitos políticos e ideológicos para 0 aparelho militar, subvertendo a hierarquia tradicional e as cadeias de comando daí derivadas. Já observada na literatura, a transformação do "modelo político" brasileiro (na expressão de Cardoso (1972)) não foi concebida originalmente "como uma volta dos militares aos quartéis, mas como a expulsão da política de dentro deles” (MARTINS, 1979-1980, p. 22).

A facção que recuperou o controle do governo depois da posse do General Geisel na presidência da República, em março de 1974 - facção marginalizada politicamente quando o General Costa e Silva tornou-se, em 1967, comandante supremo da "Revolução" (GASPARI, 2002a) -, possuía dois objetivos estratégicos, um político, outro militar: restabelecer a estrutura e a ordem no interior do estabelecimento militar, assim como garantir maior estabilidade institucional e previsibilidade política ao regime ditatorial. Para realizar a primeira dessas tarefas, a da disciplina interna, seria preciso afastar gradualmente as Forças Armadas do comando global da política nacional e conter as atividades dos setores de informação e repressão do Estado, reduzindo, com isso, uma das fontes de poder da facção rival. As mudanças impostas à organização e ao modo de funcionamento do aparelho do Estado, cujo traço mais saliente foi uma significativa centralização do poder na presidência da República, paralelamente a uma concentração do poder no Presidente da República (CODATO, 1997), visavam justamente enquadrar a extrema-direita, transferindo para a cúpula do Executivo as decisões sobre prisões, cassações e eleições.

A segunda tarefa, a da segurança do regime, equivalia a rever certos aspectos deste para institucionalizar um modelo político mais liberal, através da restauração progressiva de algumas liberdades civis mínimas. O objetivo final não era exatamente revogar o autoritarismo e instituir "a

consenso na literatura quanto ao fato de que a maioria dos soldados profissionais valoriza mais a sobrevivência e a eficácia dos próprios militares do que qualquer outra coisa [...]. A maior parte da oficialidade se preocupa mais com a unidade das forças armadas do que com o controle ou não do governo por militares” (GEDDES, 2001, p. 221, 228, 232 e 235, respectivamente). democracia”, mas tornar a ditadura militar menos conservadora politicamente ${ }^{3}$.

O projeto militar desdobrou-se num processo pendular, em que se revezaram períodos de maior e menor violência política, de acordo com uma lógica menos instrumental e mais conjuntural, traduzindo a dificuldade do governo Geisel em controlar todas as variáveis implicadas na política de transição. A política de liberalização da ditadura militar brasileira continuou no governo Figueiredo (1979-1985), sob o nome de "abertura política", graças à normalização da atividade parlamentar e à manutenção do calendário eleitoral, depois da revogação parcial das medidas de exceção (em 1978) e efetuadas a anistia política e uma reforma partidária (em 1979). A realização de eleições relativamente livres, nos anos setenta e oitenta, "geraram uma dinâmica própria” (LIMA JÚNIOR, 1993, p. 39), levando o processo de transição a diferenciar-se, em alguma medida, do projeto militar original. Assim, no Brasil a relação entre votação e democratização (da esfera política) não foi casual (LAMOUNIER, 1986), mas foi, até certo ponto, inesperada. As eleições influíram no curso dos acontecimentos ao acelerar o ritmo de transformação do regime, sem mudar, todavia, sua direção conservadora. A “Nova República” (19851990), último governo (ainda que civil) do ciclo do regime ditatorial-militar, encerra esse longo período de transição ao estabelecer a hegemonia política do partido de oposição ao regime (1986), promulgar uma Constituição (1988) e realizar uma eleição popular para Presidente (1989).

A década de noventa foi, de acordo com grande parte da literatura, o período da consolidação do regime liberal-democrático. Esse processo compreende os governos de Collor de Mello (1990-1992), Itamar Franco (1992-1995) e Fernando Henrique Cardoso (1995-2002). A “consolidação democrática” deu-se em um quadro institucional peculiar. O cenário resultante da nova Constituição conjugou o presidencialismo como a forma de governo, o federalismo como a fórmula de relação entre o Estado central e as unidades subnacionais (MAINWARING, 1997), a coalizão política como a fórmula de governabilidade

\footnotetext{
3 Para confirmar os propósitos não-democráticos do projeto de liberalização do regime, ver a longa entrevista do General Geisel ao CPDOC (D’ARAÚJO \& CASTRO, 1997).
} 
(ABRANCHES, 1988), tudo isso apoiado sobre um sistema partidário fragmentado (NICOLAU, 1996), pouco institucionalizado e demasiadamente regionalizado (ABRUCIO, 1998). Essa combinação institucional - ou, para alguns, essa deformação institucional - conduziu no final das contas o processo de transição para o seguinte ponto: uma democracia eleitoral, um Executivo imperial e um regime congressual que atua ora como colaborador, ora como sabotador das iniciativas do Presidente, ator central do sistema político ${ }^{4}$.

O objetivo deste artigo é refazer a história política nacional a partir de 1974 a fim de indicar as variáveis que influíram na configuração - política e institucional - do regime atual. Meu pressuposto não é apenas que a "história conta”, o que é um truísmo, mas que há relações causais entre o conteúdo, o método, as razões e o sentido da mudança política da ditadura brasileira para a democracia brasileira.

\section{UM MODELO DE ANÁLISE}

Parece conveniente resumir a história brasileira recente em vista dos aspectos mais significativos da transição política (1974-1989) e da consolidação democrática (1989-2002), a fim de propor uma interpretação desse período. Tal recuo, por assim dizer, diante de uma Ciência Política baseada em hipóteses gerais que se deduzem de uma tipologia da transição e de um modelo descritivo e normativo de democratização, é indispensável para se transpor o ponto de vista puramente classificatório e tentar recuperar a dimensão histórica do processo político.

A vasta literatura especializada em "transições políticas”, surgida nos anos oitenta e noventa sob inspiração do paradigma institucionalista, promoveu uma alteração importante nas análises da mudança política. O modelo de referência dominante, dito macro-estrutural, calcado em variáveis explicativas de tipo econômico e/ou social, viu-se questionado por uma abordagem que passou a enfatizar fatores eminentemente políticos na compreensão da passagem do "autoritarismo" à democracia.

\footnotetext{
4 Ainda que suas prerrogativas institucionais, principalmente legislativas, não se traduzam automaticamente na capacidade efetiva de tomar decisões e implementá-las, a Presidência da República continuou como o centro do sistema político. Para uma discussão desses aspectos relacionados à história da transição brasileira, v. Kinzo (2001).
}

Essa nova geração de trabalhos, que poderia ser agrupada sob o título pouco eufônico, mas bem preciso, de "transitologia"5 possui três características que a distinguem das análises macroorientadas: (i) ênfase no estudo dos atores políti$\cos$ - seus interesses, valores, estratégias etc. (em sintonia com a teoria da escolha racional e o individualismo metodológico; em oposição, portanto, a explicações classistas); (ii) destaque para os fatores endógenos de cada país no estudo do curso do processo de transição (e não a fatores globais do tipo "transformações no processo de acumulação capitalista”); e (iii) adoção de um conceito minimalista e pouco exigente de "democracia” (à la Schumpeter: a democracia é um método de seleção de lideranças), única forma, imaginou-se, de dar conta de uma série de casos bastante diferentes entre si. Talvez o ponto mais problemático dessas abordagens tenha sido seu excessivo conjunturalismo (REIS, REIS \& VELHO, 1997), freqüentemente a reboque das incertezas da situação política e dos compromissos ad hoc dos atores "estratégicos".

Em uma direção diferente daquela que retém unicamente o andamento da cena política e os fatores institucionais na explicação, penso que é necessário sublinhar os condicionantes políticos e ideológicos que presidiram o processo de construção da democracia política no Brasil na última década. A dimensão histórica é considerada essencial nessa abordagem ${ }^{6}$. A história recente é o pano de fundo no longo e errático processo de construção de uma ordem liberal-democrática $a$ partir do espólio do regime ditatorial-militar. Trata-se de chamar a atenção, portanto, para essa dimensão, quer por sua ausência em algumas análises formalistas da transição/consolidação, quer pela presença incidental dos "fatos" selecionados em certas narrativas, reduzidos a meros exemplos apenas para ilustrar um postulado ou confirmar uma "teoria".

A legitimidade da abordagem tipológica - típica de certa Ciência Política - não está, obviamente, em questão. Ela é tão útil quanto as interpretações macro-sociológicas inspiradas pela Sociologia Política. O que está em questão na verdade é $a$

\footnotetext{
5 O artigo de Monclaire (2001) apresenta uma competente discussão dos estudos desse tipo.

6 Para uma discussão mais detida dessa abordagem, v. Fernandes (2002).
} 
natureza das variáveis que integram a análise baseada em modelos. Mais ainda, o que se discute é se tais variáveis são ou não uma tradução, em nível abstrato, de elementos concretos produzidos historicamente. Assim, a perspectiva adotada aqui considera mais produtivo "determinar historicamente os aspectos abstratos arbitrariamente isolados para fins hermenêuticos e restituir aos protagonistas do processo político, sociologicamente concebidos como sujeitos já dados de interesses não especificados, sua concretude social, examinandoos em sua constituição e em sua evolução histórica” (QUARTIM DE MORAES, 1985).

Para que se possa elaborar uma interpretação do período em questão, deve-se apresentar, em primeiro lugar, um resumo dos “fatos” políticos, no sentido mais convencional do termo. Essas ocorrências são organizadas de acordo com uma nova proposta de periodização dos regimes, tanto o ditatorial como o democrático, em que o longo intervalo entre 1964 e 2002 é dividido em fases e as próprias fases, em etapas. Cada fase (podendo ou não sobrepor-se, como numa cronologia comum, a períodos de governo) corresponde efetivamente a um processo: constituição, consolidação, transformação etc. do modelo político. As etapas assinalam os momentos de virada no interior de cada fase e, também, entre uma fase e outra (que, em geral, coincidem com crises políticas). Trata-se de uma indicação sumária dos intervalos do processo político, já que uma explicação efetiva desse período implicaria abordar cada crise e os momentos de ruptura nesse contínuo. Em segundo lugar, são definidos os parâmetros de análise do processo político brasileiro, de acordo com a história política brasileira. Pretende-se sugerir que o programa de mudança política pode ser mais bem compreendido quando se tem presente a conexão entre quatro aspectos: o conteúdo, a natureza, as razões e o significado mais geral da transição de um regime a outro. Por fim, em terceiro lugar, procura-se compreender o movimento político entre 1974 e 2002 a partir de dois parâmetros predefinidos: as transformações na forma de Estado e as evoluções da forma de regime. Cada uma dessas variáveis recobre um espaço político diferente. A primeira permite captar as modificações nas relações de força entre os aparelhos e ramos do sistema estatal; a segunda, as disputas na cena político-partidária (POULANTZAS, 1968). As análises aqui são mais esboçadas que desenvolvidas, já que envolvem um espectro muito variado de matérias. Três temas procuram, ao final, unificar a narrativa: o militar, o político e o burocrático. $\mathrm{O}$ estilo ensaístico deste artigo deriva não apenas do nível de abstração, visto que o foco são os grandes processos, mas também de sua intenção principal: oferecer ao leitor um panorama razoavelmente fiel da história política brasileira recente.

\section{A HISTÓRIA POLÍTICA DA TRANSIÇÃO BRASILEIRA}

O golpe de 1964 assinalou uma modificação decisiva na função política dos militares no Brasil. A ação final contra a "democracia populista" (1946-1964) ou, como preferem os conservadores, a "Revolução", trouxe duas novidades. Não se tratava mais de uma operação intermitente das Forças Armadas com um objetivo preciso, quase sempre o de combater a "desordem" (a política de massas) ou o "comunismo" (a política social) ou a "corrupção” (i. e., a política propriamente dita), mas de uma intervenção permanente. A garantia política que as Forças Armadas emprestaram aos governos civis, notadamente no pós-1930, convertia-se agora num governo militar. Há, de fato, uma mudança de regime político. Da mesma forma, não mais se tratava de um pronunciamiento, em que um chefe militar de prestígio ou um grupo de oficiais se recusava a obedecer ao governo, mas de um movimento institucional das Forças Armadas (O'DONNELL, 1975; CARDOSO, 1982). Foi o aparelho militar, e não um líder político militar, que passou a controlar primeiramente o governo (i. e., o Executivo), depois o Estado (e seus vários aparelhos) e, em seguida, a cena política (i. e., as instituições representativas) ${ }^{7}$.

Se essa ação está na origem da autonomia do aparelho militar sobre o "mundo civil" depois de 1964, recorde-se que a presença dos oficiais na cena política nacional nunca foi novidade, principalmente depois da Revolução de 1930.

Contudo, as intervenções militares de 1937 (o golpe do Estado Novo) ou de 1945 (o golpe que põe fim ao Estado Novo) nada têm a ver com um

\footnotetext{
7 Esse novo gênero de intervenção, mais burocrático e menos provisório, foi seguido, com algumas diferenças regionais, por todos os regimes militares da América do Sul Brasil, Argentina, Chile e Uruguai - nas décadas de sessenta e setenta do século XX. Suzeley K. Mathias (2004) discute detalhadamente todos os aspectos relacionados ao “processo de militarização" do Estado brasileiro nesse período.
} 
suposto "padrão moderador" que as Forças Armadas desempenhariam em todas as crises políticas nacionais, mediando conflitos entre políticos civis desde a República (STEPAN, 1971). Esse hipotético "padrão" corresponde, na verdade, a uma série específica de determinações históricas, que são a fonte da autonomia política e da singularidade ideológica exibidas pelo estabelecimento militar. Elas se devem basicamente: (i) à centralização do poder militar (em dois sentidos: da base para o topo do aparelho burocrático; da periferia para o centro do sistema político); (ii) à oscilação ideológica das cúpulas das Forças Armadas, entre o getulismo em 1937 (i. e., o autoritarismo) e o antigetulismo em 1945 e 1964 (i. e., o antipopulismo); (iii) à aversão dos oficiais à política de massas, representada, no caso, pelo incentivo à mobilização sindical e à exaltação nacionalista (o que explicaria a oscilação anterior); e (iv) à atitude dos militares em relação à democracia ou, mais exatamente, sua recusa não do princípio do sufrágio universal, mas de suas conseqüências práticas: os resultados eleitorais "errados" do período 1945-1964 (QUARTIM DE MORAES, 1985).

São precisamente essas determinações históricas, esse elitismo em sentido amplo, que estão na base da intervenção das cúpulas das Forças Armadas no processo político em 1964. Cúpulas que legitimam, ou melhor, justificam seu papel dirigente em função da crise política na década de 1960, informam a estratégia de modificação do regime ditatorial nos anos 1970 , modelam a forma de governo desejada ao final dessa modificação na década de 1980 e preservam sua autonomia política e institucional nos anos 1990.

Do ponto de vista cronológico, a história política do regime ditatorial e da transição brasileira da ditadura militar para a democracia liberal pode ser assim descrita:

- Fase 1: constituição do regime político ditatorial-militar (governos Castello Branco e Costa e Silva)

- $\quad$ etapa 1: março de 1964 (golpe de Estado) - outubro de 1965 (extinção dos partidos políticos) $)^{8}$

\footnotetext{
8 Mediante o Ato Institucional n. 2 (de 27 de outubro de 1965). O sistema pluripartidário (1945-1965) é transformado em bipartidário: um partido pró-regime, a Arena (Aliança Renovadora Nacional) e um partido de oposição ao regime, o MDB (Movimento Democrático Brasileiro).
}

- etapa 2: outubro de 1965 (tornada indireta a eleição de Presidente da República) janeiro de 1967 (nova Constituição)

- etapa 3: março de 1967 (posse de Costa e Silva) - novembro de 1967 (início da luta $\operatorname{armada}^{9}$ )

- etapa 4: março de 1968 (início dos protestos estudantis) - dezembro de 1968 (aumento da repressão política ${ }^{10}$ )

- Fase 2: consolidação do regime ditatorial-militar (governos Costa e Silva e Médici)

- etapa 5: agosto de 1969 (Costa e Silva adoece; Junta Militar assume o governo) - setembro de 1969 (Médici é escolhido Presidente da República ${ }^{11}$ )

- etapa 6: outubro de 1969 (nova Constituição) - janeiro de 1973 (refluxo da luta armada)

- etapa 7: junho de 1973 (Médici anuncia seu sucessor) - janeiro de 1974 (eleição congressual (indireta) de Geisel)

- Fase 3: transformação do regime ditatorial-militar (governo Geisel)

- etapa 8: março de 1974 (posse de Geisel) - agosto de 1974 (anunciada a política de modificação do regime)

- etapa 9: novembro de 1974 (vitória do MDB nas eleições senatoriais) - abril de 1977 (Geisel fecha o Congresso Nacional)

- $\quad$ etapa 10: outubro de 1977 (demissão do Ministro do Exército) - janeiro de 1979 (revogação do Ato Institucional n. 5)

- Fase 4: desagregação do regime ditatorial-militar (governo Figueiredo)

- etapa 11: março de 1979 (posse de Figueiredo) - novembro de 1979

\footnotetext{
9 Primeira ação da Aliança Libertadora Nacional (ALN) em São Paulo sob a direção de Carlos Marighella.

10 Após a edição do Ato Institucional n. 5 (de 13 de dezembro de 1968).

11 A “eleição” do sucessor de Costa e Silva foi feita a partir da consulta ao Alto Comando das Forças Armadas (MARTINS FILHO, 1995, p. 184).
} 
(extinção dos partidos políticos Arena e MDB)

- $\quad$ etapa 12: abril de 1980 (greves operárias em São Paulo) - agosto de 1981 (Golbery pede demissão do governo)

- etapa 13: novembro de 1982 (eleições diretas para governadores dos estados; maioria oposicionista na Câmara dos Deputados) - abril de 1984 (derrotada a emenda das eleições diretas ${ }^{12}$ )

- etapa 14: janeiro de 1985 (vitória da oposição na eleição para Presidente da República) - março de 1985 (posse de José Sarney) $)^{13}$

- Fase 5: transição, sob tutela militar, para o regime liberal-democrático (governo Sarney)

- etapa 15: abril-maio de 1985 (falece Tancredo Neves; emenda constitucional restabelece eleições diretas para Presidente da República) - fevereiro de 1986 (anunciado o Plano Cruzado contra a inflação)

- etapa 16: novembro de 1986 (vitória do PMDB nas eleições gerais) - outubro de 1988 (promulgada nova Constituição)

- etapa 17: março de 1989 (início da campanha para as eleições presidenciais) - dezembro de 1989 (Collor de Mello vence as eleições presidenciais)

- Fase 6: consolidação do regime liberal-democrático (governos Collor, Itamar Franco e Fernando Henrique Cardoso)

\footnotetext{
12 O ponto máximo da campanha pelo restabelecimento das eleições diretas para Presidente da República, que começara em janeiro de 1984, em Curitiba, ocorreu em abril do mesmo ano quando um comício com as principais figuras de oposição ao regime reuniu quase 1 milhão de pessoas no Rio de Janeiro (no dia 10) e mais de um milhão em São Paulo (no dia 16). No dia 25, o Congresso Nacional rejeitou a Emenda Constitucional que previa eleições diretas já para o ano seguinte (1985). Para uma discussão da relação desses movimentos sociais com o processo de mudança do regime, v. o artigo de Rodrigues (2001).
}

13 O PDS (Partido Democrático Social), agremiação política herdeira da Arena, dividiu-se em 1984 e a facção dissidente apoiou a candidatura Tancredo Neves para a presidência da República (tendo José Sarney como vice-candidato).
- etapa 18: março de 1990 (posse do Presidente eleito, Fernando Collor de Mello; anunciado o Plano Collor I) - janeiro de 1991 (anunciado o Plano Collor II)

- etapa 19: dezembro de 1992 (impedimento do Presidente Collor; o vice-Presidente Itamar Franco assume a Presidência da República) - julho de 1994 (lançado o Plano Real)

- etapa 20: janeiro de 1995 (posse do Presidente eleito, Fernando Henrique Cardoso) - junho de 1997 (aprovada a emenda que permite a reeleição do Presidente da República e dos titulares dos poderes Executivos municipais e estaduais)

- etapa 21: janeiro de 1999 (posse do Presidente reeleito, Fernando Henrique Cardoso) - outubro-novembro de 2000 (vitória dos partidos de oposição nas eleições municipais)

- etapa 22 : julho de 2002 (início da campanha para as eleições presidenciais) janeiro de 2003 (posse do Presidente eleito, Luís Inácio Lula da Silva)

Essa periodização simplificada do cenário político assinala os limites temporais do regime ditatorial (1964-1974), do período de transição (19741989) e do intervalo da consolidação de um novo regime nacional (1989-2002) ${ }^{14}$. Ela não indica, contudo, os traços mais significativos da política brasileira contemporânea, nem permite estabelecer inferências causais que expliquem a sucessão de acontecimentos ou a passagem de uma fase a outra. Parece impossível, em todo caso, compreender a transição política e a consolidação democrática independentemente do processo político concreto. Este depende, por sua vez, da trajetória histórica nacional, assim como das condições históricas dadas em função dessa trajetória ou, na falta de um nome melhor, dos "contextos" e da interação entre os "atores": no caso, as Forças Armadas (como agente político), o Estado (como organização institucional) e a sociedade (como o conjunto de agentes sociais).

\footnotetext{
14 Cruz (2005) sugeriu uma periodização mais simplificada do regime, dividindo-o em ciclos a cada dez anos: 1964 (início: golpe de Estado); 1974 (inflexão: transição política); 1984 (fim: ápice do movimento oposicionista).
} 
A interação desses três elementos - Forças Armadas, Estado e sociedade - pode, contudo, tornar-se meramente formalista caso não sejam tomados como unidades historicamente determinadas. Já se indicou acima a origem do poder do aparelho militar sobre as demais instituições e sua distância ideológica em relação à democracia “real”. Não há espaço aqui para desenvolver os outros tópicos. Sublinhe-se apenas que uma compreensão mais extensa do "Estado" implica tomá-lo como feixe de instituições, organismos, aparelhos e agências burocráticas, cuja configuração não é indiferente, de um lado, à evolução das relações de hierarquia e subordinação entre os diversos centros de decisão e, de outro, às articulações concretas desses aparelhos (e de seus respectivos ocupantes) com as classes e grupos sociais. Da mesma forma, a "sociedade" resulta de um padrão específico de desenvolvimento capitalista ("um modelo de desenvolvimento" a partir de um "modo de produção"), graças à combinação peculiar, no âmbito de uma formação social concreta, entre a estrutura produtiva e a estrutura de classes (ABRANCHES, 1979; MARTINS, 1985).

\section{ALGUMAS VARIÁVEIS DE ANÁLISE PO- LÍTICA}

A análise da dinâmica política da transição exige que se respondam pelo menos quatro perguntas básicas:

1) O que muda? Isto é: que instituições políticas são suprimidas, restauradas ou transformadas nesse processo de evolução política?

2) Como muda? Isto é: qual a natureza do processo que governa a mudança?

3) Por que muda? Ou seja: quais as razões da substituição de um modelo político por outro?

4) Em que direção muda? Ou seja: qual o significado mais amplo que se pode atribuir à mudança política?

A primeira pergunta - o que muda no regime ao longo do tempo? - pede que se defina a natureza (conservadora, liberal, radical) e a amplitude (maior, menor) das transformações políticoinstitucionais introduzidas no modelo político pela elite (militar) dirigente. Dessa perspectiva, a abordagem do problema está colada à história política, mas não se reduz a uma simples crônica dos acon- tecimentos sob a forma de um resumo explicativo ${ }^{15}$. No sentido próprio do termo, não é uma "cronologia" (i. e., uma disposição dos fatos numa seqüência temporal reconhecível, um depois do outro), mas uma periodização: uma subdivisão temporal do espaço político que diz respeito à ação aberta ou velada das classes sociais e grupos políticos e militares. Essa periodização geral deve ser complementada por uma periodização especificamente política, o que implica em dispor, em seqüência, diferentes regimes políticos através do tempo, regimes esses que estão ligados à luta partidária na cena política (POULANTZAS, 1968). No caso específico dos regimes de ditadura militar há, no mínimo, duas complicações importantes: as "classes" não são os únicos atores do processo político (e nem os mais importantes) e os partidos tendem a perder sua função de representação, que é transferida para o aparelho de Estado. Essa transferência comporta também algumas dificuldades e complexidades, o que explica a concorrência entre setores das Forças Armadas e a elite estatal civil (os "tecnocratas"). Em resumo, ficamos assim: as cúpulas das Forças Armadas se incumbem das questões políticas e ideológicas e a elite estatal (civil), das questões de economia (CODATO, 2005).

Assim, uma periodização mais completa e rigorosa que a feita aqui deveria abranger as transformações no sistema estatal (e.g.: os deslocamentos dos centros de poder, as alterações nas suas hierarquias respectivas, bem como seu grau de "militarização") e as evoluções/involuções institucionais da cena política (e.g.: a ampliação ou restrição das "liberdades", e sua influência tanto sobre os movimentos da "sociedade civil" quanto sobre a dinâmica partidária). Esses dois níveis ou regiões do espaço político não são apenas correlatos, mas se determinam mutuamente. Não se compreende a introdução, no regime, de certas instituições e práticas liberais sem ter presente, por exemplo, a alteração nas correlações de força entre os aparelhos (e seus respectivos controladores) que integram o sistema estatal. $\mathrm{O}$ governo Geisel - e o domínio do Presidente sobre a Presidência - é o melhor caso disso que se quer dizer.

15 Bayart (1976) classifica três histórias do regime autoritário brasileiro assim: Skidmore (1967 - e poderíamos incluir SKIDMORE, 1988), Schneider (1971) e Fiechter (1974). 
A segunda pergunta - como muda o regime? equivale à exposição do processo político, com ênfase principalmente na ação dos "atores estratégicos” (MARTINS, 1979-1980, p. 20-21) e na reação dos outros "atores estratégicos" diante da ação dos primeiros. Conforme Luciano Martins, trata-se de saber quem detém a iniciativa do processo, quem detém o controle sobre ele (uma vez que, da primeira, não se segue o segundo, como seria óbvio), como se dá o arranjo ou se costuram as coalizões políticas que levam à evolução do programa de mudança e qual é, dentre os projetos políticos de transformação do regime, o preponderante (MARTINS, 1988, p. 113). A narrativa aqui obedece, em geral, à lógica da causa e efeito. Mas é sempre arriscado isolar uma variável independente que seja capaz de explicar todo o processo político. Como há sempre uma interação não apenas entre os atores políticos e os agentes sociais, mas também entre os atores e as instituições políticas, e uma vez que suas respectivas performances dependem justamente dessa interação, seria mais prudente pensar na interdependência das variáveis (políticas, econômicas, sociais, ideológicas etc.) e na mudança, ao longo do tempo, da natureza, importância e significado dessas mesmas variáveis ${ }^{16}$, que são historicamente determinadas. Não basta indicar que a auto-reforma do regime resultou de uma decisão do Presidente militar para enquadrar a burocracia militar, como parece ser o caso da compreensão de Elio Gaspari (2003; 2004). Posto em movimento, o processo de reforma do regime ditatorial-militar tende a superar (para o bem ou para o mal) o projeto original.

A terceira pergunta - por que o regime muda? - remete ao entendimento das contradições do próprio modelo e suas dificuldades de: (i) legitimação política; (ii) organização interna e (iii) evolução institucional. Esses não são, obviamente, problemas simples - nem para os analistas da política ditatorial, nem para os constitucionalistas da política ditatorial. A natureza e amplitude da

16 Couto (1998) sugere um modelo bastante complexo para entender o processo de transição política e econômica no Brasil na década de noventa. Ele argumenta que se deva integrar na análise do sistema político três dimensões simultaneamente: as instituições (e suas mudanças), os atores (e suas conversões) e o contexto político-social, que em cada conjuntura é diferente. mudança estão condicionadas ao tipo de resposta que a elite detentora da iniciativa dá-lhes.

O problema da legitimação do regime militar, por exemplo, está posto desde seu primeiro dia. Os governos militares devem estimular um "consenso ativo", o que envolveria algum grau de mobilização social com todos os riscos aí implícitos, ou devem apoiar-se num “consenso passivo”, isto é, tácito, como nas democracias liberais? ${ }^{17}$

O problema da evolução institucional tem, à primeira vista, duas faces. Uma que se refere ao Estado e seus ocupantes, outra que se refere à "sociedade civil" e seus movimentos.

Esquematicamente, a primeira dimensão está ligada à controvérsia sobre a nova função da Presidência da República (quais os limites de suas prerrogativas?) e sobre a sucessão presidencial (como escolher o sucessor?; e depois: quem indicar?). Deveria a Presidência ser o locus de coordenação política e supervisão ideológica do sistema estatal, ficando os ministérios, conselhos e comissões com a função executiva propriamente dita? Esse parece ter sido seu figurino no governo Médici. Ou ela deveria ser o aparelho que, de fato, concentra o poder de Estado, como no governo Geisel? O Presidente deveria ser considerado mero "delegado da Revolução" ou "comandante supremo" das Forças Armadas? ${ }^{18}$ Visto que o regime não criou uma regra clara para a rotatividade no poder, nem assumiu, para fins de consumo interno e externo, a figura do "ditador", como no caso do Chile, o conflito em torno da sucessão tendeu a ser sempre o mais agudo e difícil de todo o período militar (MARTINS FILHO, 1995).

Já do lado da sociedade, a evolução institucional do regime está diretamente ligada num primeiro momento à repressão (tanto seu grau, quanto seus clientes preferenciais). Em seguida, o ponto central do processo passa a ser a liberalização. Uma vez abolida a censura, liberados os presos políticos, concedida a anistia, garantido o habeas

17 Esse tópico foi discutido, a propósito da Espanha de Franco, por Juan Linz (1964). Cardoso (1972) prefere falar em “autenticação” do regime e não em legitimação política.

18 Para uma discussão particularmente ilustrativa desse último problema, v. Gaspari (2004). Sobre o primeiro, v. Cardoso (1975), Lafer (1975) e Codato (1997). 
corpus, revogado o bipartidarismo, até onde a oposição legal poderia ir? Quais os limites da contestação? O que era, do ponto de vista do grupo político-militar que dirige a transformação do regime, inegociável?

A questão da organização interna é, naturalmente, o problema do arranjo específico do sistema institucional dos aparelhos do Estado. Como ordenar e posteriormente coordenar a relação entre as partes civil e militar do sistema estatal? Como forjar uma nova estrutura de autoridade? Com base em que critérios recrutar a elite estatal? Como organizar o processo decisório? Qual o limite da influência dos militares sobre as questões políticas? etc. ${ }^{19}$ Problemas tão mais delicados ao se observar que, sob o procedimento mais geral de "hipertrofia do Estado" nos regimes ditatorial-militares, se desenvolvem uma série quase infinita de desajustes "administrativos" e distorções organizacionais. Pelo lado da burocracia: indefinição de fronteiras funcionais formais entre os ramos do Estado; sobreposição de funções e competências, fonte praticamente inesgotável de conflitos burocráticos; expansão de prerrogativas e extravasamento das esferas de competência, que geram novos focos de atrito; acirramento da competição interburocrática, desencadeada pelo movimento de conquista de espaços políticos e novos recursos de poder por parte de determinadas agências; por fim, transformação das agências burocráticas em agências de representação de interesses. Pelo lado dos burocratas: estreitamento de vínculos com aliados “externos”, i. e., sociais, como mecanismo de suporte amplamente utilizado no jogo interno de poder; articulação de alianças entre segmentos do aparelho burocrático e suas clientelas, gerando arenas privilegiadas e um estilo personalista de gestão etc. ${ }^{20}$

A última pergunta - qual a direção da mudança política? - exige que se distingam certas altera-

19 Cardoso nota que, durante o "regime autoritário”, o conflito entre Executivo-Legislativo desloca-se para o Executivo e há, efetivamente, uma concorrência entre "tecnocratas" e "militares" no processo de tomada de decisões (CARDOSO, 1982).

20 Para uma visão geral dessas questões, v. MARTINS, 1985 e ABRANCHES, 1978. Para a análise de alguns casos, v. Lima Júnior e Abranches (1987). Para uma discussão referida ao tema da "transição", v. Diniz e Boschi (1989). ções (de grau) que podem ser introduzidas no regime político, sem implicarem a transformação do regime no seu oposto (uma mudança de natureza, por assim dizer). A cúpula militar que dirige o processo de transição tem todo o interesse apenas na primeira alternativa. Ela equivale à institucionalização do regime ditatorial, mas sob outra forma política. Trata-se, paradoxalmente, de um autoritarismo sem ditadura. $\mathrm{O}$ fundamental é que o processo decisório continue centralizado no poder Executivo, os militares continuem controlando, mesmo à distância, os centros de poder real, a atividade dos partidos políticos fique restrita aos períodos eleitorais, o poder do Legislativo permaneça pouco mais que ornamental e, como lembrou Luciano Martins, a expressão da "vontade popular” não implique qualquer tipo de participação autônoma da sociedade (MARTINS, 19791980, p. 31).

O passo para se institucionalizar o autoritarismo (no sentido acima) não significa, porém, que o regime ditatorial era pouco ou nada institucionalizado ${ }^{21}$, mas que o arranjo institucional em vigor não era funcional nem estável, daí as crises políticas freqüentes (1965, 1968, 1974, 1977, 1981 etc.); que, portanto, ele deveria ser reformado para suportar essas crises, sem que isso implicasse uma regressão "populista” (ao pré1964) ou um avanço democrático.

Esses não são os únicos parâmetros da análise da história política do regime político. Mesmo as saídas às questões formuladas não podem, naturalmente, ser elaboradas em poucas páginas. Seja como for, talvez algumas respostas possam servir de fio condutor para se compreender o sentido mais geral da cronologia já esboçada e, mais importante, identificar certos determinantes históricos para explicar a substituição do "regime autoritário" pelo autoritarismo, conforme minha hipótese.

\section{ADINÂMICADAABERTURA POLÍTICANO BRASIL}

O pressuposto mais geral para a análise do movimento de abertura política no Brasil consiste em que a revogação dos regimes políticos ditatoriais e o restabelecimento de formas de governo

21 Para Linz (1973), ao contrário, tratava-se tão-somente de uma "situação autoritária”. 
democráticas, semidemocráticas ou semiditatoriais não são alcançadas necessariamente por sua derrubada ou mediante um golpe de Estado, ou ainda pela ascensão do movimento popular (POULANTZAS, 1975). Ela pode resultar também e, no caso do Brasil, principalmente, de processos evolutivos de mudança. Schmitter sugere que, desse modo, a transição para a democracia implica duas possibilidades: (i) ou há uma "transferência de poder" dos militares para os políticos aliados ao regime; (ii) ou há uma "submissão" (negociada) dos militares aos políticos da oposição moderada ao regime (O'DONNELL \& SCHMITTER, 1988). No caso do Brasil, houve um pouco das duas coisas, sem que houvesse realmente uma delas. Os militares não transferiram todo o poder ao partido do governo (Arena, depois PDS). Eles conservaram posições estratégicas no aparelho do Estado e sua capacidade de vetar certas iniciativas dos políticos civis em temas constitucionais e institucionais, como se viu na década de 1980 (a comparação com o caso argentino fala por si). A conciliação promovida pela elite política foi tão ampla que, uma vez derrotada a alternativa para a transformação do modelo político pela via eleitoral, em 1984, tanto representantes do regime quanto opositores do regime formaram o primeiro governo civil, após a aprovação das Forças Armadas22.

É conveniente reparar que o restabelecimento de formas democráticas de governo é apenas um dos resultados possíveis da transformação política dos “regimes autoritários” (MARTINS, 1988, p. 108). Como já observado por Moisés, "as transições de regime 'não democráticos' nos anos [19]70 e [19]80 [...] começaram como transições do autoritarismo para 'outra coisa', mas não há nada que assegure que essa 'outra coisa' [fosse] necessariamente um regime democrático" (MOISÉS, 1994, p. 88). A tentação da teleologia, presente em alguns estudos que pretendem identificar na transição política uma trajetória em dire-

\footnotetext{
22 Vencido o movimento pela restauração do sufrágio popular para Presidente, o Colégio Eleitoral reuniu-se em 15 de janeiro de 1985 e elegeu Tancredo Neves (PMDB) por 480 votos, contra 180 dados a Paulo Maluf (PDS). Tancredo adoeceu, não assumiu e em seu lugar tomou posse da Presidência da República em 15 de março de 1985 José Sarney, ex-líder do partido de apoio à ditadura.
}

ção a um ponto que, de qualquer forma, seria a realização plena da democracia liberal, parece enganoso em pelo menos dois sentidos. De um lado, porque certos analistas pressupõem que o objetivo estratégico dos militares que dirigem o processo é (era) "restabelecer a democracia”. De outro, porque igualmente se eximem de estimar os "restos" de autoritarismo nas instituições do novo regime e avaliar se e como eles podem afetar a estrutura institucional e a dinâmica política democrática. Aqui seria prudente evitar os estudos constitucionais comparados.

\section{V.1. O conteúdo da mudança política: institui- ções liberais, práticas autoritárias}

O projeto original da facção militar que passou a controlar o processo político após 1974, representada pelas figuras dos generais Ernesto Geisel e Golbery do Couto e Silva (os "castellistas"23), foi muito mais de "mudança política" que de "transformação política”. A variante adotada deveria comportar uma liberalização do regime ditatorial, mas não necessariamente a democratização do sistema político (STEPAN, 1988, p. 12-13) ${ }^{24}$. Na Espanha, enquanto a "transição democrática" seguiu uma via condicional - cada instituição democrática introduzida no sistema político exigia (isto

23 Adeptos do Marechal Castello Branco, primeiro Presidente do regime ditatorial brasileiro. Os "castellistas” são comumente associados, de maneira equivocada, a posições "liberais", enquanto seus opositores nas Forças Armadas, a "linha dura”, são associados a posições "radicais”. Mais fiel aos fatos, uma divisão desses grupos deveria associar os primeiros à institucionalização do regime e, os últimos, à administração da repressão. Não é demais lembrar que foram exatamente os "liberais" do Exército criaram o Serviço Nacional de Informações (em junho de 1964), editaram o Ato institucional n. 2 (em outubro de 1965), que suprimiu os partidos políticos e tornou indireta, a partir de então, as eleições presidenciais; foi essa linha "moderada" também que promulgou uma nova Constituição (em janeiro de 1967) e fechou o Congresso Nacional (em abril de 1977), introduzindo uma série de mudanças ("casuísmos”, segundo a expressão da época) na legislação eleitoral. Oliveiros Ferreira (2000) propõe uma outra divisão entre as duas principais correntes político-ideológicas das Forças Armadas: o "estabelecimento militar", i. e., aqueles que agiriam de acordo com a legalidade constitucional, e o "partido fardado", i. e., aqueles militares dispostos a intervir na política para estabelecer a lei e a ordem constitucional.

24 Para a diferença entre os dois processos e suas possibilidades de interação, v. O’Donnell e Schmitter (1988). 
é, condicionava) outra -, no Brasil, a via da mudança política foi seqüencial: certos direitos liberais clássicos foram reintroduzidos de acordo com uma estratégia incremental e moderada, sob a direção do governo e com a colaboração da oposição "responsável”, a fim de se evitarem os riscos de uma regressão autoritária (SKIDMORE, 1988, p. 323-325) ${ }^{25}$. Em que pese a diferença entre Brasil e Espanha, Share e Mainwaring (1986) traçaram um útil paralelo entre os dois países no que diz respeito ao modo da mudança política, chamado por eles “transição pela transação", enfatizando o caráter negociado de todo o processo ${ }^{26}$.

O propósito do governo Geisel (1974-1979) foi promover uma distensão, isto é, um relaxamento dos controles políticos impostos à sociedade. A censura prévia foi parcialmente suspensa, os resultados eleitorais, depois de algumas manipulações das regras ${ }^{27}$, foram admitidos, os protestos dos empresários contra o "modelo econômico" foram, embora com reservas, tolerados e as inesperadas reivindicações operárias, surgidas a partir de 1978, foram um efeito não antecipado da ação liberalizante. Esse projeto foi mantido, no governo Figueiredo (1979-1985), sob o nome de "política de abertura", com lances controversos e sob oposição da extrema-direita militar. Concluída no fim do governo Sarney (1985-1990), a "transição política” (de 1974 a 1989) foi peculiar: ela durou, ironicamente, mais que o regime pro-

25 O desenho mais geral desse programa reformista pode ser lido em Santos (1978, p. 143-211). Em um artigo intitulado "Estratégias de descompressão política”, Santos enfatizou a necessidade de retomarem-se certos direitos liberais clássicos, sob uma estratégia gradual e moderada, com a cooperação da oposição, de modo a evitar os riscos de um retrocesso político. A primeira medida deveria ser a eliminação da censura e a garantia da liberdade de expressão. Para uma análise concreta dos mecanismos de funcionamento da censura no Brasil durante o regime, v. Soares (1989).

26 Santos (2000) demonstrou que, por caminhos semelhantes, o resultado das duas transições foi o mesmo: predomínio do poder Executivo sobre o Legislativo. Uma comparação entre a redemocratização na Espanha, Brasil e Argentina pode ser lida em Schmidt (1990). Para uma discussão sobre as implicações metodológicas desse tipo de comparação, v. Bunce (2000).

27 Para compreender a série de “casuísmos” que alteraram o processo político graças à manipulação do sistema eleitoral (cujos resultados nem sempre foram favoráveis ao regime ditatorial), v. Fleischer (1986). priamente dito (1964-1974). Sua principal característica foi o continuísmo excepcional do autoritarismo (MARTINS, 1988) nas instituições do governo civil que deveria, afinal, ser "de transição”. Stepan e Linz já sugeriram que "a duração incomum da transição brasileira”, quando comparada com a de outros países, está relacionada "ao fato de que o regime autoritário [...] era hierarquicamente controlado por uma organização militar que detinha poder suficiente para controlar o ritmo da transição e para extrair um alto preço por se retirar do poder" (LINZ \& STEPAN, 1999, p. 205$)^{28}$.

Esse é, basicamente, o lado político da estratégia. Há que se considerar também seu lado militar. Uma das tarefas mais importantes e difíceis na mudança da fórmula política foi o desengajamento gradual das Forças Armadas da condução cotidiana dos negócios de Estado e seu retorno à condição usual de guardiã da ordem interna. Um dos principais ingredientes dessa política foi o fortalecimento do Presidente da República e a afirmação de sua autoridade sobre os vários grupos e facções da própria corporação militar, em especial aqueles que controlavam os órgãos de segurança e que haviam conquistado ampla liberdade nos governos anteriores (ou, como se dizia, "autonomia operacional”), agindo como um poder paralelo dentro do Estado (QUARTIM DE MORAES, 1982, p. 771; GASPARI, 2002b). Outra peculiaridade da mudança: a vitória do Presidente militar sobre a corporação militar deu-se mediante um acréscimo de autoritarismo, e não seu contrário. Daí que a demissão do Ministro do Exército Sylvio Frota, em outubro de 1977, tenha sido um dos lances mais influentes desse processo (GASPARI, 2004) ${ }^{29}$, a ponto de permitir indicar a forma da mudança política.

28 Salvo engano, Alfred Stepan foi o primeiro autor a sugerir a importância da manutenção de "enclaves autoritários” no aparelho do Estado (dirigidos pelos militares) mesmo após a vigência do que a maioria dos autores chama de “democracia”, i. e., o governo Sarney (v. STEPAN, 1986). Para mais informações sobre a possibilidade de supervisão do processo constituinte pelas Forças Armadas (1987-1988), v. Zaverucha e Teixeira (2004).

29 O General Geisel, note-se, venceu as três crises militares de seu governo: demitiu o comandante do II Exército (1976), exonerou o Ministro do Exército (1977) e aceitou imediatamente o pedido de dispensa do Chefe da Casa Militar (1978). Sobre o tema, v. Oliveira (1980). 
V.2. O método de mudança política: centralização e controle

A legenda do governo Geisel foi, como se sabe, distensão política "lenta, gradual e segura”. Esse procedimento deveria ser suficientemente arrastado para que não pudesse ser interpretado como uma involução da "Revolução", servindo de pretexto à contestação aberta da extrema-direita, militar e civil. Ele deveria ser também gradual, isto é, progressivo e limitado, pois não poderia abrir caminho a uma ofensiva oposicionista que conduzisse, por exemplo, à uma ruptura democrática (QUARTIM DE MORAES, 1982, p. 766-767). E deveria ser controlado pelo próprio Presidente, uma vez que as duas tarefas anteriores exigiam supervisão estrita tanto dos movimentos políticos da direita militar como da esquerda parlamentar. Só assim se reconstitui o sentido da estratégia pendular de Geisel, ora à direita (cassações), ora à esquerda (eleições) ${ }^{30}$.

Todavia, como já se enfatizou acima, o projeto original de liberalização do regime ditatorial não foi idêntico ao processo político que ele desencadeou. Uma vez iniciado, o movimento adquiriu lógica própria e as várias crises nos governos Geisel e Figueiredo dizem respeito tanto à tentativa dos Presidentes de reafirmar seu controle sobre o processo, quanto da oposição civil e militar de alterar o projeto (em direções diferentes). A complicação era mais ou menos a seguinte: se a "distensão política”, sob a tutela dos militares, era a única forma imaginada pela elite no poder para resolver as contradições do aparelho militar e do próprio "regime militar”, a "abertura política” permitiu a intervenção do empresariado nacional, das camadas médias e dos trabalhadores no jogo político. Logo, as fases e etapas indicadas na periodização acima não podem ser reduzidas, exclusivamente, à dinâmica política e burocrática do aparelho militar (suas lutas internas, guerras ideológicas ou disputas entre personalidades ${ }^{31}$ ). Em grande medi-

\footnotetext{
30 O General Golbery do Couto e Silva, principal assessor do Presidente Geisel, descreveu esse processo com uma metáfora questionável. As sucessivas modificações do sistema político para adaptar-se aos conflitos embutidos na dinâmica da transição poderiam ser considerados perfeitamente naturais, à maneira de "sístoles” e “diástoles” (v. SILVA, 1981).

31 Para uma boa visão dessa questão, v. Oliveira (1994). Em Gaspari (2002a; 2002b; 2003; 2004) há uma história
}

da, a periodização do regime ditatorial corresponde também a três rearranjos: (i) à nova geografia que se estabeleceu entre políticos e militares, em que as eleições são o melhor indicador para se apurar o grau crescente de importância dos "civis" na cena política; (ii) à redefinição das relações de força entre as classes sociais (CRUZ \& MARTINS, 1983), em que a passagem da posição hegemônica de uma fração de classe (capital industrial multinacional e nacional associado) a outra (capital bancário) é ilustrativa das novas contradições entre "governo" e "empresariado"32; (iii) à redefinição das relações de forças entre as classes e o estabelecimento militar, atestada pelos protestos crescentes de trabalhadores e profissionais de classe média (advogados por meio da $\mathrm{OAB}$, jornalistas por meio da $\mathrm{ABI}$ etc.). Ainda que indiretamente, as greves e a ascensão dos movimentos sociais traduzem o ritmo do "renascimento da sociedade civil”33.

Os dados das votações para o legislativo estadual e federal ilustram a evolução da oposição parlamentar, sugerindo sua crescente importância no sistema político.

Mantidas pelo regime as instituições da democracia representativa clássica (partidos, parlamentos e eleições) $)^{34}$, o entendimento da transformação do sistema político tem de passar necessariamente pela análise da influência da dinâmica eleitoral sobre o processo político nas décadas de setenta e oitenta. As tabelas adiante (tabelas 1 e 2) resumem os resultados das eleições legislativas no Brasil entre 1966 e 1986. Se dividirmos os votos em duas correntes opostas, "situação" (Arena) e "oposição" (MDB), teremos o seguinte:

detalhada das contradições presentes no interior da instituição militar. Essa é, segundo o autor, a variável explicativa da transição.

32 Sobre a mudança de hegemonia, cf. Saes (1990). Para um balanço crítico da literatura a respeito dos conflitos entre a burguesia brasileira e o poder Executivo militar, v. Codato (1995).

33 Há imensa literatura sobre o tema; cf., em especial, Sader (1988).

34 O’Donnell e Schmitter afirmam que o regime brasileiro "não presenciou qualquer tentativa séria de criação de instituições autoritárias”; os militares governaram “recorrendo amplamente à distorção, e não à destruição das instituições básicas da democracia política” (O’DONNELL \& SCHMITTER, 1988, p. 46; sem grifos no original). 
TABELA 1 - RESULTADOS OFICIAIS DAS ELEIÇÕES LEGISLATIVAS, POR PARTIDO POLÍTICO (BRASIL, 1966-1982 - EM \%)

\begin{tabular}{|l|c|c|c|c|c|c|c|c|c|}
\hline & \multicolumn{3}{|c|}{ SENADO FEDERAL } & \multicolumn{3}{c|}{ CÂMARA DOS DEPUT ADOS } & \multicolumn{3}{c|}{ ASSEMBLÉIAS ESTADUAIS } \\
\hline Anos & Arena & MDE & B\&N & Arena & MDB & B\&N & Arena & MDB & B\&N \\
\hline 1966 & 44,7 & 34,2 & 21,2 & 50,5 & 28,4 & 21 & 52,2 & 29,2 & 18,6 \\
\hline 1970 & 43,7 & 28,6 & 27,7 & 48,4 & 21,3 & 30,3 & 51 & 22 & 26,8 \\
\hline 1974 & 34,7 & 50 & 15,1 & 40,9 & 37,8 & 21,3 & 42,1 & 38,8 & 18,9 \\
\hline 1978 & 35 & 46,4 & 18,6 & 40 & 39,3 & 20,7 & 41,1 & 39,6 & 19,3 \\
\hline $1982^{*}$ & 36,5 & 50 & 13,5 & 36,7 & 48,2 & 15,1 & 36 & 47,2 & 16,8 \\
\hline
\end{tabular}

Fonte: Tribunal Superior Eleitoral.

Notas:

1. Arena: Aliança Renovadora Nacional; MDB: Movimento Democrático Brasileiro; B\&N: votos brancos e nulos.

2. Os votos do PDS foram artificialmente incluídos na coluna "Arena" e os da oposição ao regime (Partido do Movimento Democrático Brasileiro (PMDB), Partido dos Trabalhadores (PT), Partido Democrático Trabalhista (PDT), Partido Trabalhista Brasileiro (PTB)), na coluna "MDB".

TABELA2 - RESULTADOS OFICIAIS DAS ELEIÇÕES LEGISLATIVAS, POR PARTIDO POLÍTICO E SOMENTE VOTOS VÁLIDOS (BRASIL, 1986 - EM \%)

\begin{tabular}{|c|c|c|c|c|c|c|c|c|c|}
\hline & \multicolumn{3}{|c|}{ SENADO FEDERAL } & \multicolumn{3}{c|}{ CÂMARA DOS DEPUT ADOS } & \multicolumn{3}{c|}{ ASSEMBÉ́IAS EST ADUAIS } \\
\hline Ano & "Arena" & "MDE" & Outros & "Arena" & "MDE" & Outros & "Arena" & "MDB" & Outros \\
\hline $1986^{*}$ & 18,4 & 81,6 & - & 29,5 & 68,3 & 1,7 & 30,4 & 66,2 & 3,4 \\
\hline
\end{tabular}

Fonte: Nicolau (1998, p. 56-58, 95, 173-175).

Nota: Os votos do PDS-Partido Progressista Renovador (PPR), Partido da Frente Liberal (PFL), Partido Liberal (PL) e Partido Democrata Cristão (PDC) foram incluídos na coluna "Arena" e os dos partidos de oposição ao regime (PMDB, PT, PDT, PTB, Partido Socialista Brasileiro (PSB), Partido Comunista Brasileiro (PCB) e Partido Comunista do Brasil (PCdoB)) foram incluídos na coluna "MDB". Essas agremiações, MDB e Arena, foram extintas em 1979.

Como se pode notar, o que deveria ser apenas uma fachada liberal para o regime ditatorial converteu-se num poderoso elemento de dinamização do programa da transição, em especial no início dos anos oitenta. Uma inspeção ligeira nesses números permite, ao menos, quatro conclusões: (i) a votação do partido da situação é, ao longo do tempo, inversamente proporcional à do partido da oposição; (ii) ainda que o ritmo do crescimento do voto oposicionista seja diferente nas três casas legislativas (maior no Senado federal, menor nas Assembléias Legislativas estaduais), ele é praticamente constante; (iii) ao fim da primeira série temporal (1982), a oposição controla em torno de $50 \%$ do eleitorado, enquanto o partido da situação, 36\%; (iv) o único momento em que a série se modifica (1970) corresponde ao crescimento dos votos nulos e em branco, a forma possível, naquela conjuntura, de protesto contra o regime. Daí que em 1979 o "reconhecimento da impossibilidade do governo assegurar uma sólida base de apoio par- lamentar tornou imperativa a dissolução do sistema bipartidário” (KINZO, 1988, p. 224).

É provável, como argumentou Lamounier (1986), que a arena eleitoral tenha sido mais importante no caso brasileiro que em outros processos de transição política, nos anos setenta, na América Latina. Há que se levar em conta, porém, o outro lado da moeda. Nem todas as classes ou camadas encontraram, como salientou Saes, o lugar privilegiado para se oporem ao regime ditatorial na "cena político-partidária”, já que o MDB, o partido contrário ao governo, mantevese praticamente afastado dos movimentos populares. O instrumento da moderna classe operária foi na verdade o sindicato. Assim, a forma de "ação oposicionista mais eficaz [...] não foi o voto, e sim a greve” (SAES, 1984, p. 227).

A Tabela 3 é um indicativo para que se possa medir a dissociação da sociedade do regime e de seu modelo econômico. 
TABELA 3 - NÚMERO TOTAL DE GREVES, NÚMERO MÉDIO DE TRABALHADORES PARADOS, JORNADAS NÃO TRABALHADAS E MÉDIADE DIAS PARADOS, NAS REGIÕES URBANAS (BRASIL, 1978-1987)

\begin{tabular}{|c|c|c|c|c}
\hline ANO & $\begin{array}{c}\text { TOTAL DE } \\
\text { GREVES }\end{array}$ & $\begin{array}{c}\text { NÚMERO MÉDIO DE } \\
\text { TRABALHADORES PARADOS }\end{array}$ & $\begin{array}{c}\text { JORNADAS NÄO } \\
\text { TRABALHADAS }\end{array}$ & $\begin{array}{c}\text { MÉDIA DE DIAS } \\
\text { PARADOS }\end{array}$ \\
\hline 1978 & 118 & 1868 & 2162903 & 6,5 \\
\hline 1979 & 246 & 9777 & 26627083 & 6,6 \\
\hline 1980 & 144 & 9012 & 24225695 & 7,4 \\
\hline 1981 & 150 & 6107 & 6545003 & 8,8 \\
\hline 1982 & 144 & 4934 & 6967215 & 5,9 \\
\hline 1983 & 347 & 3689 & 28407743 & 4,4 \\
\hline 1984 & 492 & 2946 & 13311365 & 3,9 \\
\hline 1985 & 619 & 11016 & 90637512 & 6,3 \\
\hline 1986 & 1004 & 5181 & 49525864 & 5,8 \\
\hline 1987 & 2193 & 4187 & 132445423 & 8,2 \\
\hline
\end{tabular}

Fonte: NEPP (1989, p. 129-131 - dados selecionados a partir das Tabelas 1, 2, 3 e 4).

Nota: Em relação ao número médio de trabalhadores parados, foram contabilizados os trabalhadores da indústria; trabalhadores da construção civil; assalariados de classe média; trabalhadores do setor de serviços e outras categorias profissionais.

Em paralelo à evolução da oposição partidária, os dois últimos governos militares, de Geisel e de Figueiredo, tiveram de enfrentar uma forma mais moderna de organização política, o "novo sindicalismo" 35 . Esse desafio insere-se num contexto mais amplo e que diz respeito ao processo de reestruturação do sistema de representação de interesses da sociedade junto ao Estado. Por ora, basta notar que a dinâmica sindical cruza-se, nessa conjuntura, com a dinâmica político-partidária sem que haja, no entanto, uma relação de determinação entre elas.

Ao observar apenas a coluna "total de greves" da Tabela 3, pode-se supor que, nesse intervalo de dez anos (i. e., 1978-1987), a transformação de 118 paralisações (1978) em 2193 (1987) deva ter tido sua função no processo de conversão do regime. A informação mais importante é, contudo, o aumento em quase dez vezes do número de trabalhadores parados entre 1978 e 1979. Embora exa-

\footnotetext{
35 Em resumo, o "novo sindicalismo" consistia numa maneira diferente de organização dos trabalhadores em relação ao sindicato oficial de Estado (criado no período posterior a 1930) e também numa maneira diferente de apresentar reivindicações salariais. O ponto fundamental era a tentativa de negociar a questão diretamente com os empresários, sem a mediação do Ministério do Trabalho. Para uma visão otimista do fenômeno, v. Maroni (1978); para uma análise geral da evolução do novo sindicalismo, da década de 1970 para a de 1980, v. Keck (1988). Ao lado desse fenômeno surgiram, no final dos anos setenta, novos movimentos sociais urbanos. Uma boa perspectiva histórica dessa questão pode ser lida em Ottmann (1995).
}

gerando o argumento, Diniz (1986) parece ter razão ao afirmar que a "abertura política” é o resultado de duas dinâmicas que atuam simultaneamente no sistema político: a dinâmica das negociações no universo das elites e a dinâmica das pressões da sociedade (camadas médias, classe operária) sobre o Estado militar. Talvez seja o caso de sugerir que a primeira dinâmica estabeleceu o conteúdo, definiu o modo e impôs a natureza da transição, enquanto a segunda determinou seu ritmo.

\section{V.3. As razões da mudança política: um regime em crise perene}

Os processos políticos que estão na base da reforma do regime ditatorial em 1974 não são idênticos aos que presidiram sua origem em 1964 (MARTINS, 1979-1980, p. 19). Cada um deles corresponde a uma crise política específica, mas tendo as Forças Armadas como protagonista principal.

Se pudermos associar o surgimento das ditaduras na América Latina a dois tipos de fatores, um de natureza estrutural - elas corresponderam à necessidade de reorganizar o modelo de acumulação capitalista na periferia (O'DONNELL, 1975) - e outro de natureza conjuntural - a percepção pelos militares brasileiros de uma situação de caos social e desordem burocrática que exigia sua "intervenção" (SOARES, 1994) ${ }^{36}$ -, é preciso recordar que a razão para mudar a forma

\footnotetext{
36 Para uma formalização elegante dessa explicação v. Geddes (2001, p. 233-235).
} 
de governo, em 1974, obedece antes a dificuldades internas do próprio "regime militar". Dificuldades essas que têm origem no ramo militar do aparelho do Estado (DREIFUSS \& DULCI, 1983), repercutem nas Forças Armadas e se ampliam a partir delas para outros aparelhos e ramos. Daí que não se deva associar o propósito reformista de Geisel-Golbery a motivos mais globais do tipo "crise econômica" ou "crise social”. A crise econômica (medida, por exemplo, pelo aumento da inflação e desequilíbrio do balanço de pagamentos) foi paralela à auto-reforma da ditadura. $\mathrm{E}$ a crise social (representada tanto pelos resultados negativos da política de "distribuição de renda", quanto pela reação a ela: as greves) foi revelada pelos efeitos liberalizantes da política de auto-reforma da ditadura.

$\mathrm{O}$ que não significa dizer que o regime ditatorial-militar tenha sido estável. No Brasil, por exemplo, o regime nunca alcançou um estado ótimo de equilíbrio político entre políticos liberais, líderes conservadores e militares reacionários. Tampouco obteve consenso entre os próprios militares, visto que a existência de diversos grupos rivais nas Forças Armadas denunciava a presença de vários projetos ideológicos, principalmente sobre a natureza - provisória ou duradoura - e os objetivos - amplos ou restritos - de sua intervenção na vida política nacional, depois de 1964.

Por isso mesmo, o regime brasileiro teve dificuldade para encontrar uma fórmula institucional definitiva. Foi um regime em crise permanente, como freqüentemente ocorre nessas formas políticas de exceção (POULANTZAS, 1975). A própria ausência de uma regra clara para a sucessão de chefes militares na Presidência é um indício do conflito insolúvel entre um modelo político que pretende preservar sua imagem civilizada, já que não quer recorrer à figura clássica do "ditador latino-americano", e a impossibilidade de "civilizar" o comando do Estado, isto é, transferir a um político civil confiável, o posto de Presidente da República. Os problemas clássicos do consenso e da coerção - o grau de consentimento da sociedade e a intensidade da repressão por parte do Estado - foram também razão e expressão das dificuldades para criar instituições políticas próprias. O descontrole sobre os "porões" (CENIMAR, DOPS, DOI-CODI ${ }^{37}$ etc.) ainda que aparecesse como "anarquia” (conforme a percep-

37 Centro de Informações da Marinha; Delegacia de Ordem Política e Social; Destacamento de Operações de Informações - Centro de Operações de Defesa Interna. ção de Gaspari, por exemplo), era a forma mais ou menos normal, ou possível naquela conjuntura, de combater uma oposição real (a luta armada) ou imaginária (“os comunistas”). Por sua vez, o custo para produzir um consenso ativo que se aproximasse da legitimidade ficava muito dependente dos ciclos de expansão econômica, sendo as campanhas publicitárias pró-ditadura e a "educação moral e cívica” modestíssimos exemplos de fabricação de uma cultura autoritária dominante e efetiva, em tudo diferente aqui, portanto, da exaltação nacionalista "varguista".

Em suma, penso que a ausência de ordem/hierarquia entre os ramos do aparelho do Estado e a precariedade de um sistema próprio de justificação ideológica (à la Estado Novo, por exemplo) decorreu basicamente de três problemas combinados: (i) da dificuldade em construir uma estrutura "racional" para tomada de decisões, como sugerem as freqüentes reformas administrativas do Estado38; (ii) da falta de coerência e coesão ideológicas entre os diversos grupos, civis e militares, que comandavam a política nacional ${ }^{39}$, e (iii) da inexistência de regras claras e fixas para a evolução institucional, cujo sintoma mais aparente era a incerteza sobre quem comandaria o governo, como o poder seria exercido e em que direção o regime deveria caminhar ${ }^{40}$.

Em vista disso, pode-se presumir que o objetivo estratégico da reconversão liberal do regime militar era a institucionalização de uma série de dispositivos autoritários (QUARTIM DE MORAES, 1982, p. 766) que, depois de encerrado o ciclo dos generais, garantissem legitimidade, estabilidade e funcionalidade a um novo modelo

38 O sistema decisório correspondeu a diversos arranjos, seguindo a correlação de forças no interior da burocracia civil e militar. V., para esse problema, Lafer (1975), Martins (1985) e Codato (1997).

39 Entre os militares havia os internacionalistas, adeptos de uma economia de mercado mais “aberta”, e os nacionalistas de direita, partidários de uma "economia nacional" industrialmente desenvolvida. Uma ala civil liberal apoiara o golpe de Estado e via no aprofundamento da repressão política, em 1968, um “desvio autoritário” dos seus propósitos originais. Nessa visão, o golpe era uma "contrarevolução” que barrou "a implantação de uma república sindicalista no País, com o apoio ostensivo do governo de [Fidel] Castro" (cf. 30 ANOS DEPOIS, 1994, p. A3).

40 Sobre esse último ponto é ilustrativo o depoimento do General Hugo Abreu (1979). 
político nem "populista”, nem plenamente "democrático", em função dos riscos do segundo converter-se no primeiro. De novo. Tal como tinha sido o caso, na visão das Forças Armadas, do regime da Constituição de 1946.

\section{V.4. O sentido da mudança política: a institu- cionalização do autoritarismo}

Os governos militares não inventaram suas próprias instituições político-representativas: por exemplo, um partido mobilizador de massa. A "reforma partidária” de 1965 (o AI-2) limitou-se a cancelar os registros das antigas agremiações, criadas após o período do Estado Novo, reorganizando as facções pró-regime e anti-regime em apenas duas siglas, respectivamente: Arena e MDB. Da mesma forma, o sistema de representação de interesses não se orientou na direção de um corporativismo "clássico" (como havia sido tentado pela Constituição de 1934), mas também não conseguiu encontrar a fórmula ideal para refazer, num contexto antiliberal, as conexões entre "sociedade" e "Estado". Nesse caso em especial, a ligação entre certos setores do empresariado e determinados centros decisórios no aparelho do Estado foram aprofundadas nas administrações Costa e Silva e Médici de acordo com o mesmo modelo dos conselhos técnicos do autoritarismo "varguista". Contudo, esse esquema, pelas distorções que criava no sistema estatal (balcanização, fragmentação, entropia etc.), e foi revogado no governo Geisel, mas restaurado e ampliado no governo Figueiredo (CODATO, 1997).

Se essas evidências confirmam a precariedade da ditadura para edificar uma estrutura jurídico-política, não significam que o Brasil tenha vivido uma "situação autoritária" (LINZ, 1973). Tampouco suas crises periódicas e a instabilidade característica do regime ditatorial daí derivada são um índice do caráter transitório ou incipiente do “modelo político”. Há duas confusões nesse raciocínio. Uma que associa inconstância a baixa institucionalização; e outra que vincula instituições ao processo de institucionalização. A presença ou ausência de certas instituições é menos importante que a função que elas cumprem na dinâmica política concreta. Tome-se o caso do sistema bipartidário. Concebido para discriminar, controlar aliados e dissidentes, seu funcionamento, uma vez estabelecido um calendário eleitoral mais ou menos fixo e postos alguns cargos políticos à disposição da concorrência eleitoral, foi um fator, ao longo do tempo, tanto de estabilidade (até 1974) quanto de instabilidade para o regime (de 1974 em diante) ${ }^{41}$.

Contudo, como os principais cargos executivos nunca estiveram em disputa (Presidência da República, governo dos estados, prefeituras das capitais), as crises políticas que a dinâmica eleitoral produziu não foram suficientes para revogar o traço fundamental do regime ditatorial: o monopólio político do governo pelas Forças Armadas. A impossibilidade da "alternância no poder" entre grupos civis (mesmo os mais conservadores) e militares é a referência mais segura da institucionalização da ditadura. Quando, no início do governo Geisel, há um impulso para a modificação do regime, não se trata, na minha opinião, de "um projeto de institucionalização do regime autoritário, que prevê medidas liberalizantes, mas apenas na medida em que sirvam a esse propósito" (CRUZ \& MARTINS, 1983, p. 46). Trata-se da institucionalização do autoritarismo, ou, mais exatamente, da institucionalização de certos dispositivos de controle da sociedade pelo Estado. Nas palavras tortuosas do Presidente Ernesto Geisel: "Os instrumentos excepcionais de que o governo se acha armado para manutenção da atmosfera de segurança e de ordem [...] almejo vêlos não tanto em exercício duradouro ou freqüente, [mas] antes como potencial de ação repressiva ou de contenção mais enérgica e, assim mesmo, até que se vejam superados pela imaginação política criadora, capaz de instituir, quando for oportuno, salvaguardas eficazes e remédios prontos e realmente eficientes dentro do contexto institucional” (DISCURSO DE GEISEL, 1974, p. 5).

A imaginação política criadora posta em prática deu no seguinte: em outubro de 1978, o Congresso Nacional aprovou a Emenda Constitucional n. 11 (à Constituição de 1967), que conjugava reformas políticas com a permanência das "salvaguardas eficazes”. Ela abolia o Ato Institucional n. 5, restabelecendo o habeas corpus, suspendia a censura prévia para rádio e TV, revogava as penas de morte e prisão perpétua, restaurava a independência do Judiciário etc. Mas também garantia, ao mesmo tempo, os poderes discricioná-

\footnotetext{
41 É o caso, por exemplo, das eleições para o Senado Federal, que assumiram um caráter plebiscitário anti-regime. V. a Tabela 1, acima.
} 
rios do Executivo. No lugar do AI-5 foram introduzidas na Constituição certas "salvaguardas para a defesa do Estado", tais como o "estado de emergência”. Excluída a necessidade de consultas prévias ao Congresso, o estado de emergência poderia ser decretado pelo próprio Presidente da República. Ao contrário do que ocorria no AI-5, o Presidente não estava autorizado a legislar, mas a imunidade parlamentar não foi totalmente restabelecida. Embora o chefe do Executivo não mais pudesse cassar mandatos e suspender direitos políticos, os parlamentares seriam processados pela ditadura nos casos de "crimes contra a segurança nacional" 42 .

Esse problema da institucionalização de dispositivos autoritários de controle do poder de Estado, diante da possibilidade de perda de comando do processo político em função de um possível, mas ainda incerto, relaxamento dos controles repressivos, estava na ordem do dia desde o início da década de 1970. Quando assumiu o governo, o grupo do General Geisel já havia descartado tanto um regime corporativista, que os assessores de Médici haviam defendido em 1970-1971, quanto a transformação da Aliança Renovadora Nacional num partido dominante, ao estilo do PRI mexicano, conforme a idéia proposta por Samuel Huntington (SKIDMORE, 1988, p. 321). A opção que prevaleceu foi a de implantar uma forma de governo mais estável, previsível e controlada, em que o sistema de partidos e a rotina eleitoral, que surpreendentemente haviam se convertido, na década de setenta, num meio poderoso de protesto contra o regime, não pusesse em xeque o autoritarismo; nem desse oportunidade aos "excessos” do período populista, representados pelo avanço da mobilização popular sob o comando de uma liderança "carismática e demagógica”.

Feitas as contas, quando se consideram a natureza conservadora do processo de transição no Brasil, seus meios autoritários e seus objetivos restritos, não surpreendem as razões do continuísmo do mesmo grupo no poder após 1985, ainda que às custas de seu transformismo político; nem o fato de que todo o processo de refor-

\footnotetext{
42 Cf. a íntegra da legislação em O Estado de S. Paulo de 21 de setembro de 1978. Essas reformas institucionais, que deveriam entrar em vigor em 15 de março de 1979, foram antecipadas para $1^{\circ}$ de janeiro, antes mesmo da posse do novo Presidente.
}

ma tenha sido dirigido e executado pela mesma associação de políticos profissionais e generais autoritários. A longevidade da tríade Arena-PDS-PFL na cena política ${ }^{43}$ não nos deixa esquecer que não houve uma verdadeira substituição dos grupos ligados à ditadura, mas uma reacomodação no universo das elites, tendo as Forças Armadas passado para o fundo do palco, sem contudo perder suas prerrogativas, como o poder de veto, por exemplo ${ }^{44}$.

O governo Sarney (1985-1990) foi a expressão máxima desse círculo de ferro que, com sucesso, controlou a mudança política no Brasil. Recorde-se que as palavras de ordem da Aliança Democrática, “conciliação” e "pacto social”, conseguiram neutralizar tanto os ensaios de oposição ao regime ditatorial surgidos na conjuntura 19771980 (greves operárias, movimentos sociais “de base" e protestos empresariais contra a "intervenção do Estado na economia”), quanto a famosa campanha pelas eleições diretas para Presidente da República, em 1984. O resultado foi o aperfeiçoamento de um regime antipopulista e antipopular ou, como o denominou Florestan Fernandes, uma “democracia forte", isto é, uma forma política nem explicitamente ditatorial, a ponto de ser combatida como tal, nem plenamente democrática e liberal (FERNANDES, 1981, p. 10).

A década de 1980 consumou assim os sonhos dos generais: uma "democracia relativa”, na curiosa expressão de Geisel. Logo, seria mais correto caracterizar o governo Sarney não como um governo "de transição" para a democracia ou um governo "misto" (semidemocrático ou semiditatorial), mas o último governo, no caso, civil, do ciclo de governos não-democráticos no Brasil $^{45}$. Saes argumentou justamente que seria possível pensar desse modo desde que se abrisse

\footnotetext{
43 Para uma visão mais detalhada do sucesso eleitoral dos partidos de direita no Brasil nesse período, v. Mainwaring, Menegello e Power (2000).

44 Carvalho argumenta, a meu ver com razão, que "As Forças Armadas brasileiras não foram obrigadas a aceitar um papel radicalmente diferente daquele assumido na fase autoritária, quando elas tiveram maiores responsabilidades na implementação de políticas públicas e no condicionamento da postura dos demais atores” (CARVALHO, 2004, p. 136).

45 A sugestão para caracterizar o regime brasileiro como um regime misto, em que se encontram combinadas instituições liberais e instituições autoritárias, é de Martins (1977).
} 
mão de analisar "separadamente, isto é, uma a uma, as 'instituições políticas' reintroduzidas a partir da 'abertura', [deixando] de lado a questão do tipo de relação mantida entre essas 'instituições' e as demais” (SAES, 1988, p. 18).

Uma série de liberdades políticas ou instituições tipicamente democráticas podem estar presentes mesmo num regime ditatorial. A questão central é a função precisa que, por exemplo, o pluripartidarismo ou as eleições majoritárias desempenham. No governo Sarney, essas instituições cumpriram a função de "ocultar o caráter em última instância militarizado do processo decisório estatal" (SAES, 1988, p. 19). Zaverucha (1994), nessa mesma linha, demonstrou, de forma convincente, que o governo Sarney manteve as prerrogativas políticas dos militares e "os enclaves autoritários dentro do aparelho de Estado", contribuindo para o estabelecimento de uma "democracia tutelada" 46 .

Essa proposição tem duas implicações analíticas. Não só a liberalização do regime ditatorial não se confunde com a democratização do sistema político, mas essa liberalização imposta pelas cúpulas militares foi "mais um fator de continuidade que um fator de colapso da ditadura" (FERNANDES, 1981, p. 28). Não houve propriamente uma ruptura com o autoritarismo, mas uma transformação - lenta, segura e gradual - da forma de governo. McSherry (1995) sustentou que as instituições militares latino-americanas conservaram a cultura organizacional da Guerra Fria e a ideologia da segurança nacional. No Brasil, os princípios da Lei de Segurança Nacional ainda continuam em vigor e a Constituição Federal de 1988

\footnotetext{
46 Para a função “tutelar” das Forças Armadas, v. Oliveira (1987). Para uma visão comparativa desse problema - entre Brasil, Argentina e Espanha -, v. Zaverucha (1992). Para uma argumentação semelhante, v. Camargo (1990). Barros (1988) criticou, durante os debates na Assembléia Nacional Constituinte em 1988, as visões juridiscistas sobre a função "constitucional” das Forças Armadas e as tentativas formalistas de impedir, pela via legal, intervenções políticas ou golpes militares. Saint-Pierre e Mathias (2001) reuniram uma série de estudos sobre o sucesso ou insucesso do controle dos militares pelos civis durante os processos de mudança política em sete países da América Latina.
}

assegurou as funções das Forças Armadas para manter "a lei e a ordem" no país ${ }^{47}$.

\section{UMADEMOCRACIAAUTORITÁRIA?}

Na década de noventa, a maior parte das análises sobre a democratização do regime dissociou as transformações político-institucionais das alterações dos aparelhos estatais.

A discussão pública, seja no âmbito acadêmico, seja no âmbito político, voltou-se para algumas questões muito específicas, como por exemplo: a estrutura dos partidos (e seu baixo grau de institucionalização); o sistema de partidos (e seu alto grau de fragmentação); o sistema eleitoral (e sua fórmula "disfuncional": proporcional com lista aberta); o sistema de governo (o federalismo e a competição entre as unidades nacionais); $a$ forma de governo (presidencialista e suas impropriedade); as relações intergovernamentais (a concorrência entre os poderes Executivo e Legislativo) etc. $\mathrm{O}$ foco quase exclusivo da literatura sobre a cena política colocou no primeiro plano do debate o tema (conservador) da governabilidade, que, inspirado por uma definição minimalista da democracia, se tornou o problema fundamental do processo de governo, obscurecendo o problema da transformação do sistema estatal.

A questão do Estado e da sua crise esteve mais associada ao problema da eficiência dos gastos públicos e sua solução, a "reforma do Estado", a uma perspectiva mais administrativa (ou "gerencial"48) que a aspectos essenciais da reconfiguração das relações de força/influência do sistema estatal e dos seus aparelhos de poder. De certa forma, a preocupação com as relações Exe-

\footnotetext{
47 De acordo com o Art. 142 da Constituição de 1988 da República Federativa do Brasil, “As Forças Armadas, constituídas pela Marinha, pelo Exército e pela Aeronáutica, são instituições nacionais permanentes e regulares, organizadas com base na hierarquia e na disciplina, sob a autoridade suprema do Presidente da República, e destinam-se à defesa da Pátria, à garantia dos poderes constitucionais e, por iniciativa de qualquer destes, da lei e da ordem” (BRASIL, 1988).

48 V., a propósito, Bresser-Pereira (2001, p. 2), para quem a mudança na forma de gestão da "administração pública" foi correlata à democratização do sistema político: “Em síntese, no plano político transitamos do Estado oligárquico ao Estado democrático (de elites); no administrativo, do Estado patrimonial ao Estado gerencial”.
} 
cutivo-Legislativo ou, mais propriamente, com a capacidade do Presidente de tomar decisões e implementá-las ${ }^{49}$, sobrepôs-se às preocupações com o próprio poder Executivo, ou melhor, com os deslocamentos internos das relações de força entre os aparelhos do Estado, relegando ao segundo plano a identificação dos novos centros de poder real (e dos seus controladores) e suas conexões com os interesses sociais.

Uma dimensão importante da herança institucional da ditadura militar para os governos da década de noventa foi a permanência de núcleos de poder específicos no Estado brasileiro, dotados de grande independência e nenhum controle político (i. e., parlamentar) ou social (i. e., público). Nos governos Cardoso (1995-1998; 19992002), para ficarmos no melhor exemplo, houve três expressões desse fenômeno. Na área econômica continuou vigorando, assim como no arranjo ditatorial, o esquema do "superministério", agora representado pela tríade Banco Central, Conselho de Política Monetária e Ministério da Fazen$\mathrm{da}^{50}$. Na área militar foram mantidos três "feudos burocráticos” intocáveis: o Gabinete de Segurança Institucional (antiga Casa Militar), a Agência Brasileira de Inteligência (ABIN, antigo Serviço Nacional de Informações (SNI)) e a Justiça Mili$\operatorname{tar}^{51}$. Por fim, na área "empresarial”, i. e., naqueles aparelhos de Estado em que, por sua natureza

49 De acordo com Palermo (2000), há na literatura quatro interpretações sobre o processo legislativo e, desse modo, sobre a natureza do novo regime político: (i) o Presidente concorre com o Congresso Nacional; (ii) o Presidente exclui o Congresso; (iii) o Presidente obriga o Congresso a cooperar; (iv) o Presidente negocia com o Congresso. Neste último caso, a governabilidade depende da formação de coalizões amplas.

50 Loureiro e Abrúcio (1999, p. 70) observaram que “[...] o Ministério da Fazenda tornou-se o principal núcleo de poder do gabinete presidencial brasileiro, especialmente no primeiro governo Fernando Henrique Cardoso”. Para os autores, porém, isso decorre das exigências da governabilidade. Para contornar os efeitos do clientelismo, já que a distribuição de cargos é o método por excelência para garantir a maioria parlamentar, o Ministério da Fazenda deve ser elevado "a órgão superior e controlador do gabinete [ministerial como um todo], espalhando sua lógica de atuação pelos [demais] ministérios por meio de mecanismos formais e informais" (idem, p. 85).

51 Sobre a autonomia e o grau de militarização da ABIN, v. Antunes (2002). A respeito da atuação do Superior Tribunal Militar e as dificuldades daí decorrentes para uma democratização efetiva, v. Zaverucha e Melo Filho (2004). ou competência, se administram os "interesses do mercado" (política de privatizações, política de transportes, de comércio exterior, de comunicações, de educação etc.), a regra foi o contato direto de representantes influentes do mundo dos grandes negócios com decisores estratégicos, mecanismo muito pouco transparente e que, a propósito do "regime autoritário", Cardoso (1975) conceituou como "anéis burocráticos".

Se esse paralelismo entre certos aspectos da organização do sistema estatal em dois regimes diferentes não for apenas formal, como realmente parece não ser, por que ele ocorre? Esse padrão não-democrático da relação Estado-sociedade permanece por uma razão básica. Quando se inspeciona a agenda que vigorou no governo de Fernando Henrique Cardoso, destacam-se as famosas reformas "orientadas para o mercado": privatizações de empresas estatais, desregulamentações de esferas antes reguladas pelo Estado, controle rigoroso da inflação e do déficit público, redimensionamento dos "gastos sociais” (nas áreas de educação, saúde e previdência), abertura comercial e financeira etc. Na verdade, as reformas econômicas prescindiram de uma verdadeira reforma política, que aumentasse a representação, e de uma reforma do Estado, que favorecesse a participação. Ou melhor, as reformas neoliberais tiveram como precondição o arranjo autoritário dos processos de governo e a ausência de responsabilidade (accountability) dos governantes. Daí que sua implementação não combinou com as exigências de ampliação da cidadania e controle social sobre o Estado, suas burocracias e aparelhos de poder ${ }^{52}$. Houve uma complementaridade entre o discurso ideológico liberal e as práticas políticas autoritárias, expressa na insistência em construir apenas a hegemonia social do capitalismo neoliberal, e não novas formas de legitimação política democrática. O déficit de cidadania é somente a face mais visível desse processo.

\footnotetext{
52 Martins (2005) caracteriza dessa forma o regime político ao fim do processo de transição: “O que está aí não é nada de mais; é apenas um regime liberal a funcionar normalmente - com a ressalva de que a pureza do liberalismo encontra-se aqui tisnada por algumas manchas de corporativismo e nódoas de tecnocratismo. Tirante essas máculas - que, por sinal, nada têm de democráticas -, estamos simplesmente diante de um caso corriqueiro de pluralismo liberal” (idem, p. 19). Para uma conclusão oposta à sustentada aqui, v. Sallum Júnior (2003).
} 
Adriano Nervo Codato (adriano@ufpr.br) é professor de Ciência Política na Universidade Federal do Paraná (UFPR), coordenador do Núcleo de Pesquisa em Sociologia Política Brasileira e editor da Revista de Sociologia e Política. É autor de Sistema estatal e política econômica no Brasil pós-64 e organizou Political Transition and Democratic Consolidation: Studies on Contemporary Brazil.

\section{REFERÊNCIAS BIBLIOGRÁFICAS}

ABRANCHES, S. H. 1978. The Divided Leviathan : State and Economic Policy Formation in Authoritarian Brazil. PhD. Dissertation. University of Cornell.

1979. Uma perspectiva de análise política estrutural. Dados, Rio de Janeiro, n. 20, p. 4769.

1988. Presidencialismo de coalizão : o dilema institucional brasileiro. Dados, Rio de Janeiro, v. 31, n. 1, p. 5-33.

ABREU, H. 1979. O outro lado do poder. Rio de Janeiro : Nova Fronteira.

ABRUCIO, F. L. 1998. Os barões da federação : os governadores e a redemocratização brasileira. São Paulo : Hucitec.

AGUIAR, R. A. R. 1986. Os militares e a Constituinte : poder civil e poder militar na Constituição. São Paulo : Alfa-Ômega.

ANTUNES, P. C. B. 2002. SNI \& ABIN : uma leitura da atuação dos serviços secretos brasileiros ao longo do século XX. Rio de Janeiro : Fundação Getúlio Vargas.

BARROS, A. 1988. Problemas de transição democrática na frente militar : a definição do papel dos militares, a mudança da doutrina e a modernização do país. Política e Estratégia, Brasília, v. 6, n. 2, p. 206-214, abr.-jun.

BAYART, J.-F. 1976. L'analyse des situations autoritaires : étude bibliographique. Revue Française de Science Politique, Paris, v. 26, n. 3, p. 483-520, juin.

BRESSER-PEREIRA, L. C. 2001. Do Estado patrimonial ao gerencial. In : PINHEIRO, P. S.; WILHEIM, J. \& SACHS, I. (orgs.). Brasil : um século de transformações. São Paulo : Companhia das Letras.

BUNCE, V. 2000. Comparative Democratization : Big and Bounded Generalizations. Comparative Political Studies, Seattle, v. 33, n. 6-7, p. 703734, Aug.-Sept.
CAMARGO, A. 1990. República : conservadorismo versus modernidade. Análise \& Conjuntura, Brasília, v. 5, n. 2, p. 175-181, maioago.

CARDOSO, F. H. 1972. O modelo político brasileiro e outros ensaios. São Paulo : Difel.

.1975. Autoritarismo e democratização. Rio de Janeiro : Paz e Terra.

1982. Da caracterização dos regimes autoritários na América Latina. In : COLLIER, D. (org.). O novo autoritarismo na América Latina. Rio de Janeiro : Paz e Terra.

CODATO, A. N. 1995. A burguesia contra o Estado? Crise política, ação de classe e os rumos da transição. Revista de Sociologia e Política, Curitiba, n. 4-5, p. 55-87, jun.-nov.

. 1997. Sistema estatal e política econômica no Brasil pós-64. São Paulo : Hucitec.

. 2005. O processo decisório de política econômica na ditadura militar brasileira e o papel das Forças Armadas. Conferência apresentada no Laboratório de Estudos sobre Militares e Política (LEMP), em setembro, na Universidade Federal do Rio de Janeiro (UFRJ). Digit.

(ed.). 2006. Political Transition and Democratic Consolidation: Studies on Contemporary Brazil. New York: Nova Science Publishers.

COUTO, C. G. 1998. A longa constituinte : reforma do Estado e fluidez institucional no Brasil. Dados, Rio de Janeiro, v. 41, n. 1, p. 51-86.

CRUZ, S. V. 2005. As peripécias do quatro na política brasileira. Lua Nova, São Paulo, n. 64, p. 39-45, jan.-abr.

CRUZ, S. V. \& MARTINS, C. E. 1983. De Castello a Figueiredo : uma incursão na préhistória da "abertura". In : SORJ, B. \& ALMEIDA, M. H. T. (orgs.). Sociedade e política no Brasil pós-64. São Paulo : Brasiliense. 
D’ARAÚJO, M. C. \& CASTRO, C. (orgs.). 1997. Ernesto Geisel. Rio de Janeiro : Fundação Getulio Vargas.

DINIZ, E. 1986. A transição política no Brasil : perspectivas para a democracia. Sociedade $e$ Estado, Brasília, v. 1, n. 2, p. 65-88, jul.-dez.

DINIZ, E. \& BOSCHI, R. 1989. A consolidação democrática no Brasil : atores políticos, processos sociais e intermediação de interesses. In : DINIZ, E.; BOSCHI, R. \& LESSA, R. (orgs.). Modernização e consolidação democrática no Brasil : dilemas da Nova República. São Paulo : Vértice.

DREIFUSS, R. A. \& DULCI, O. S. 1983. As Forças Armadas e a política. In : SORJ, B. \& ALMEIDA, M. H. T. (orgs.). Sociedade e política no Brasil pós-64. São Paulo : Brasiliense.

FERNANDES, A. S. A. 2002. Path dependency e os estudos históricos comparados. BIB, Rio de Janeiro, n. 53, p. 79-102.

FERNANDES, F. 1981. A ditadura em questão. São Paulo : T. A. Queiroz.

FERREIRA, O. S. 2000. Vida e morte do partido fardado. São Paulo : Serviço Nacional de Aprendizagem Comercial.

FIECHTER, G. A. 1974. O regime modernizador do Brasil : 1964-1972. Rio de Janeiro : Fundação Getúlio Vargas.

FLEISCHER, D. 1986. Governabilidade e abertura política : as desventuras da engenharia política no Brasil, 1964-84. Revista de Ciência Política, Belo Horizonte, v. 29, n. 1, p. 1239, jan.-mar.

GASPARI, E. 2002a. A ditadura envergonhada. São Paulo : Companhia das Letras.

. 2002b. A ditadura escancarada. São Paulo : Companhia das Letras.

2003. A ditadura derrotada. São Paulo : Companhia das Letras.

2004. A ditadura encurralada. São Paulo : Companhia das Letras.

GEDDES, B. 2001. O que sabemos sobre democratização depois de vinte anos? Opinião Pública, Campinas, v.7, n. 2, p. 221-252, nov.

KECK, M. 1988. O "novo sindicalismo" na transição brasileira. In : STEPAN, A. (org.). De- mocratizando o Brasil. Rio de Janeiro : Paz e Terra.

KINZO, M. D. G. 1988. Oposição e autoritarismo. Gênese e trajetória do MDB : 1966-1979. São Paulo : Vértice.

2001. A democratização brasileira : um balanço do processo político desde a transição. São Paulo em Perspectiva, v. 15 n. 4, p. 3-12, out.-dez.

LAFER, C. 1975. O sistema político brasileiro : estrutura e processo. São Paulo : Perspectiva.

LAMOUNIER, B. 1986. Authoritarian Brazil revisitado : o impacto das eleições na abertura política brasileira, 1974-1982. Dados, Rio de Janeiro, v. 29, n. 3, p. 283-317.

LIMA JÚNIOR, O. B. 1993. Democracia e instituições políticas no Brasil dos anos 80. São Paulo : Loyola.

LIMA JÚNIOR, O. B. \& ABRANCHES, S. H. (orgs.). 1987. As origens da crise : Estado autoritário e planejamento no Brasil. São Paulo : Vértice.

LINZ, J. 1964. An Authoritarian Regime : the Case of Spain. In : ALLARD, E. \& LITTUNEN, Y. (eds.). Cleavages, Ideologies, and Party Systems. Helsinki : Westermark Society.

1973. The Future of an Authoritarian Situation and the Institutionalization of an Authoritarian Regime : the Case of Brazil. In : STEPAN, A. (ed.). Authoritarian Brazil : Origins, Policies, and Future. Baltimore : Johns Hopkins University.

LINZ, J. \& STEPAN, A. 1999. A transição e consolidação da democracia : a experiência do Sul da Europa e da América do Sul. São Paulo : Paz e Terra.

LOUREIRO, M. R. \& ABRUCIO, F. L. 1999. Política e burocracia no presidencialismo brasileiro : o papel do Ministério da Fazenda no primeiro governo Fernando Henrique Cardoso. Revista Brasileira de Ciências Sociais, São Paulo, v. 14, n. 41, p. 69-89, out.

MAINWARING, S. 1997. Multipartism, Robust Federalism and Presidentialism in Brazil. In : MAINWARING, S. \& SHUGART, M. S. (eds.). Presidentialism and Democracy in Latin America. Cambridge : Cambridge University. 
MAINWARING, S.; MENEGUELLO, R. \& POWER, T. 2000. Partidos conservadores no Brasil contemporâneo : quais são, o que defendem, quais são suas bases. São Paulo : Paz e Terra.

MARONI, A. A. 1982. A estratégia da recusa : análise das greves de maio/78. São Paulo : Brasiliense.

MARTINS FILHO, J. R. 1995. O palácio e a caserna : a dinâmica militar das crises políticas na ditadura (1964-1969). São Carlos : UFSCAR.

MARTINS, C. E. 1977. Capitalismo de Estado e modelo político no Brasil. Rio de Janeiro : Graal.

2005. Vinte anos de democracia? Lua Nova, São Paulo, n. 64, p. 13-37.

MARTINS, L. 1979-1980. A política (e os limites) da "abertura". Ensaios de Opinião, Rio de Janeiro, v. 15, p. 18-33, dez.-ago.

1985. Estado capitalista e burocracia no Brasil pós-64. Rio de Janeiro : Paz e Terra.

1988. A “liberalização" do regime autoritário no Brasil. In : O’DONNELL, G.; SCHMITTER, P. \& WHITEHEAD, L. (orgs.). Transições do regime autoritário : América Latina. São Paulo : Vértice.

MATHIAS, S. K. 2004. A militarização da burocracia : a participação militar na administração federal das comunicações e da educação, 19631990. São Paulo- : UNESP.

MCSHERRY, J. P. 1995. Military Political Power and Guardian Structures in Latin America. Journal of Third World Studies, Americus (Georgia), v. 12, n. 1, p. 80-119, Spring.

MOISÉS, J. A. 1994. Entre a incerteza e a tradição política : uma crítica da primeira geração de estudos da transição. Novos Estudos Cebrap, São Paulo, v. 40, p. 88-100, nov.

NEPP. 1989. Brasil 1987 : Relatório da situação social do país. Campinas : Núcleo de Estudos de Políticas Públicas da Universidade Estadual de Campinas.

NICOLAU, J. M. 1996. Multipartidarismo, maiorias parlamentares e democracia : notas sobre o caso brasileiro. In : DINIZ, E. (org.). $O$ desafio da democracia na América Latina. Rio de Janeiro : IUPERJ.

(org.). 1998. Dados eleitorais do Brasil (1982-1996). Rio de Janeiro : Revan.

O'DONNELL, G. 1975. Reflexiones sobre las tendencias de cambio del Estado burocráticoautoritário. Buenos Aires : CLACSO.

O'DONNELL, G. \& SCHMITTER, P. 1988. Transições do regime autoritário : primeiras conclusões. Rio de Janeiro : Vértice.

O'DONNELL, G.; SCHMITTER, P. \& WHITEHEAD, L. 1986. Transitions from Authoritarian Rule. Baltimore : Johns Hopkins University.

OLIVEIRA, E. R. 1980. Conflits militaires et décisions sous la présidence du Général Geisel. In : ROUQUIÉ, A. (org.). Les partis militaires au Brésil. Paris : Fondation Nationale Des Sciences Politiques.

1987. O aparelho militar : papel tutelar na Nova República. In : QUARTIM DE MORAES, J.; COSTA, W. P. \& OLIVEIRA, E. R.. (orgs.). A tutela militar. São Paulo : Vértice.

1994. De Geisel a Collor : Forças Armadas, transição e democracia. Campinas: Papirus.

OTTMANN, G. 1995. Movimentos sociais urbanos e democracia no Brasil : uma abordagem cognitiva. Novos Estudos Cebrap, São Paulo, v. 41, p. 186-207, mar.

PALERMO, V. 2000. Como se governa o Brasil? O debate sobre instituições políticas e gestão de governo. Dados, Rio de Janeiro, v. 43, n. 3, p. 521-557.

POULANTZAS, N. 1968. Pouvoir politique et classes sociales. Paris : F. Maspero.

1975. La crise des dictatures. Portugal, Grèce, Espagne. Paris : F. Maspero.

QUARTIM DE MORAES, J. 1982. Les militaires et les régimes politiques au Brésil de Deodoro à Figueiredo (1889-1979). Paris : Institut D’Etudes Politiques de Paris.

1985. Alfred Stepan e o mito do poder moderador. Filosofia Política, Porto Alegre, v. 2, p. 163-199, inverno.

REIS, E. P.; REIS, F. W. \& VELHO, G. 1997. As Ciências Sociais nos últimos 20 anos : três 
perspectivas. Revista Brasileira de Ciências Sociais, São Paulo, v. 12, n. 35, p. 7-28, fev.

SADER, E. S. 1988. Quando novos personagens entraram em cena : experiências, falas e lutas dos trabalhadores da grande São Paulo (19701980). Rio de Janeiro : Paz e Terra.

SAES, D. 1984. Classe média e sistema político no Brasil. São Paulo : T. A. Queiroz.

1988. O processo político brasileiro, da "Abertura” à "Nova República" : uma "transição para a democracia” (burguesa)? Teoria \& Política, São Paulo, n. 9, p. 11-28.

SAINT-PIERRE, H. L. \& MATHIAS, S. K. (orgs.). 2001. Entre votos e botas : as Forças Armadas no labirinto latino-americano do novo milênio. São Paulo : UNESP.

SALLUM JÚNIOR, B. 2003. Metamorfoses do Estado brasileiro no final do século XX. Revista Brasileira de Ciências Sociais, São Paulo, v. 18, n. 52, p. 35-55, jun.

SANTOS, F. 2000. Escolhas institucionais e transição por transação : sistemas políticos de Brasil e Espanha em perspectiva comparada. Dados, Rio de Janeiro, v. 43, n. 4, p. 637-669.

SANTOS, W. G. 1978. Poder e política : crônica do autoritarismo brasileiro. Rio de Janeiro : Forense-Universitária.

SCHMIDT, B. V. 1990. Trajetórias críticas e reconstrução política na Espanha, Argentina e Brasil. Sociedade e Estado, Brasília, v. 5, n. 2, p. 175-191, jul.-dez.

SCHNEIDER, R. M. 1971. The Political System of Brazil : Emergence of a Modernizing Authoritarian Regime, 1964-1970. New York : Columbia University.

SHARE, D. \& MAINWARING, S. 1986. Transição pela transação : democratização no Brasil e na Espanha. Dados, Rio de Janeiro, v. 29, n. 2, p. 207-236.

SILVA, G. C. 1981. Conjuntura politica nacional : o poder Executivo \& Geopolítica do Brasil. Rio de Janeiro : J. Olympio.
SKIDMORE, T. 1967. Politics in Brazil, 19301964. An Experiment in Democracy. New York : Oxford University.

1973. Politics and Economic Policy Making in Authoritarian Brazil, 1937-1971. In : STEPAN, A. (ed.). Authoritarian Brazil : Origins, Policies and Future. New Haven : Yale University.

1988. The Politics of Military Rule in Brazil, 1964-85. Oxford : Oxford University.

SOARES, G. A. D. 1989. Censura durante o regime autoritário. Revista Brasileira de Ciências Sociais, São Paulo, v. 4, n. 10, p. 21-43, jun.

1994. O golpe de 64. In : SOARES, G. A. D. \& D’ARAÚJO, M. C. (orgs.). 21 anos de regime militar : balanços e perspectivas. Rio de Janeiro : Fundação Getúlio Vargas.

STEPAN, A. 1971. The Military in Politics : Changing Patterns in Brazil. Princeton : Princeton University.

1986. Os militares : da abertura à Nova República. Rio de Janeiro : Paz e Terra.

1988. Introdução. In : (org.). Democratizando o Brasil. Rio de Janeiro : Paz e Terra.

ZAVERUCHA, J. 1992. As prerrogativas militares nas transições brasileira, argentina e espanhola. Revista Brasileira de Ciências Sociais, São Paulo, v. 7, n. 19, p. 56-65, jun.

1994. Relações civil-militares no primeiro governo da transição brasileira : uma democracia tutelada. Revista Brasileira de Ciências Sociais, São Paulo, v. 9, n. 26, p. 162-178, out.

ZAVERUCHA, J. \& MELO FILHO, H. C. 2004. Superior Tribunal Militar : entre o autoritarismo e a democracia. Dados, Rio de Janeiro, v. 47, n. 4 , p. 763-797.

ZAVERUCHA, J.; MELO FILHO, H. C. \& TEIXEIRA, H. B. 2004. Présence et ingérence des militaires dans la politique brésilienne (1964-2004) : une synthèse bibliographique. Lusotopie, Paris, v. 12, p. 399-413. 


\section{OUTRAS FONTES}

30 anos depois. 1994. O Estado de S. Paulo, 31.mar., Editorial, p. A3.

BRASIL. 1988. Constituição da República Federativa do Brasil. Brasília : Congresso Nacional. Disponível em : https://
www.planalto.gov.br/ccivil_03/Constituicao/ Constitui\%E7ao.htm. Acesso : 19.jun.2006.

Discurso de Geisel define os rumos do País. 1974. O Estado de S. Paulo, 19.ag 